\title{
Do Stringent Environmental Policies Deter FDI? M\&A versus Greenfield
}

\author{
Sylwia Bialek ${ }^{1,2} \cdot$ Alfons J. Weichenrieder $^{3,4,5}$ (D)
}

Accepted: 5 August 2021 / Published online: 8 September 2021

(C) The Author(s) 2021

\begin{abstract}
Strict environmental regulation may deter foreign direct investment (FDI). The paper develops the hypothesis that regulation predominantly discourages FDI that is conducted as Greenfield investment rather than mergers and acquisitions (M\&A). The hypothesis is tested with German firm-level FDI data. Empirically, stricter regulation reduces new Greenfield projects in polluting industries, but indeed has a much smaller impact on the number of M\&As. This significant difference is compatible with the fact that existing operations often benefit from grandfathering rules, which provide softer regulation for pre-exisiting plants, and with the expectation that for M\&As part of the regulation is capitalized in the purchase price. The heterogeneous effects help explaining mixed results in previous studies that have neglected the mode of entry.
\end{abstract}

Keywords Environmental stringency $\cdot$ Entry mode $\cdot$ Pollution haven hypothesis $\cdot$ Foreign direct investment

JEL Classification F23 · F64 · Q50 - Q58

\begin{abstract}
We would like to thank the Deutsche Bundesbank for providing access to the MiDi database and for its hospitality as well as the World Economic Forum for access to its environmental indices. The paper has significantly benefited from the comments by an anonymous referee. We are also grateful to seminar participants at McGill University, the University of Notre Dame, Dresden, Calgary, and OxCarre.
\end{abstract}

\footnotetext{
Alfons J. Weichenrieder

a.weichenrieder@em.uni-frankfurt.de

1 Institute for Policy Integrity, New York University, New York, USA

2 German Council of Economic Experts, Wiesbaden, Germany

3 Goethe University Frankfurt, Frankfurt a.M., Germany

4 Vienna University of Economics and Business, Vienna, Austria

5 CESifo, Munich, Germany
} 


\section{Introduction}

According to the pollution haven hypothesis $(\mathrm{PHH})$, differences in environmental regulation change patterns of trade and foreign direct investment (FDI), causing polluting economic activities to relocate from environmentally stringent jurisdictions to more lenient ones.

When it comes to the FDI channel, the theoretical predictions on pollution havens have gained only mixed empirical support on the macro and micro levels. ${ }^{1}$ Although many studies find support for the PHH, a considerable share of the publications indicates a small or non-existent impact of environmental regulations on investment patterns.

The mixed findings could be due to a heterogeneity in the FDI that was not controlled for in the studies. In this paper we propose that the mode of entry - an important characteristic of investments that has been neglected in the PHH studies - is such a heterogeneity factor. Mode of entry describes whether a cross-border investments was conducted by starting a new subsidiary from scratch (Greenfield investment), or by gaining ownership of an existing firm (merger and acquisition, M\&A). ${ }^{2}$ With the help of a simple model, we first explain how the choice between M\&A and Greenfield interacts with location choice and environmental regulation. We then develop an empirical strategy to identify the role of entry mode in the context of PHH and apply it to data on German outward FDI.

There are two reasons why Greenfield projects may react more strongly to environmental regulation than M\&As. Firstly, environmental requirements may be stricter for Greenfield than for M\&A investment because of vintage differentiation rules (VDR). VDRs are a quintessential feature of environmental law in many countries. They set the standards to be "fixed with respect to the date of entry of regulated units, with later vintages facing more stringent standards" (Stavins 2006). Through VDRs, plants in operation at the time of the enactment of new regulatory requirements are exempted from these requirements or granted an extended period for transformation. Consequently, VDRs might give a strong competitive advantage to the industries, firms, and regions where preexisting plants are located. Their presence implies that a multinational company performing M\&A type of investment will need to adhere to a milder set of regulations than a comparable Greenfield investment.

Secondly, in the case of M\&A, the acquisition price should be a function of the regulation faced by the company. As the purchaser of an existing plant is only willing to pay the discounted value of future profits, a company whose profits prospects are reduced through tight environmental regulation will have a lower valuation and acquisition price than a company subject to lax regulation. For Greenfields, on the other hand, the investment costs depend on the cost of inputs (construction materials, wages, etc.) that are less likely to correlate with environmental stringency.

The model captures the capitalization and VDR channel to help understand how a multinational decides about the location of its new investment, when it is also free to choose the investment entry mode. The derivations combine the location choice literature like Carlton (1983) with insight from studies on investments when firms have Melitz-style heterogenous productivities (Melitz 2003), in particular with Stepanok (2015).

\footnotetext{
${ }^{1}$ For a study of the influence of environmental regulation on trade, see Aichele and Felbermayr (2012).

${ }^{2}$ For a discussion on the modes of entry and stylized facts around them, see Davies et al. (2018) .
} 
The hypothesis developed in this paper is that because of the capitalization effect and the VDR effect Greenfield projects have a significantly higher sensitivity with respect to environmental requirements than M\&A investments. When testing this hypothesis, we allow that firms can substitute between the two entry modes for FDI.

The availability of statistics that classify FDI by their mode of entry is very restricted. In 2004, the OECD suggested that administrative FDI data should include information on the type of FDI. Before that, to the best of the authors' knowledge, solely Great Britain and Canada systematically collected such statistics on the national level ${ }^{3}$, and, so far, few countries have implemented the OECD's recommendations. Internationally, UNCTAD has been providing data on cross-border M\&As since 1990 (on Greenfields since 2002). However, the reliability of those data has often been questioned (Fujita 2008). This paucity of data could be one of the reasons why the entry mode has been neglected in the PHH literature.

The present study uses German outbound FDI data. There are two main reasons for this choice. First, Germany was one of the first countries to gather administrative information on the entry mode (starting in 2005). Second, German investment behavior should be particularly relevant in the PHH context as Germany is one of the largest economies with $10 \%$ of total world exports ( $\mathrm{Ng} 2011)$ and a share of 5-8\% in the world FDIs in the years considered according to UNCTAD data.

Our main finding is that the likelihood of a country to be chosen as a host of a new German FDI interactively depends on its environmental stringency, the industry of the project, and the mode of entry. Simulations imply that Greenfields in pollution intensive industries are approximately four times more elastic than M\&As in their reaction to a tightening of environmental stringency.

The reminder of the paper consists of six parts. Section 2 reviews the empirical PHHFDI literature, Sect. 3 discusses channels through which the choice of entry mode relates to environmental regulation and derives a model of FDI choice. Section 4 presents the empirical implementation of the model: the data used, estimation strategy as well as estimation results. Next, we discuss our robustness checks, including instrumenting environmental stringency, alternative measure of environmental regulation, and alternative econometric specification. Section 6 analyses the economic significance of the findings, whereas Sect. 7 provides concluding remarks.

\section{Patchy Evidence for Pollution Havens and FDI}

Empirical investigations of the PHH started in the 1980s, resulting in a plethora of studies that use a variety of methods and data sources to examine the relationship between environmental regulation and FDI. A review of the literature ${ }^{4}$ reveals very mixed conclusions reached by those studies: While some publications confirm PHH (Xing and Kolstad (2002), Wagner and Timmins (2009), Kellenberg (2009), Hanna 2010, Naughton 2014, Chung 2014), other studies find no effects of environmental stringency on cross-border investments (Bartik 1988, Levinson 1996, Javorcik and Wei 2005, Raspiller and Riedinger 2008, Dean et al. 2009, Manderson and Kneller 2011), and yet other studies hint at the opposite effect - the "green haven effect" (Poelhekke and van der Ploeg 2014).

\footnotetext{
${ }^{3}$ However, the respective data collection was far from perfect and relied strongly on newspaper reports.

4 More detailed overviews of the literature are available in Brunnermeier and Levinson (2004), Dong et al. (2012), and Cole et al. (2017).
} 
A possible explanation for the surprisingly mixed results could be heterogeneity in the effects of the environmental stringency on cross-border investments that the literature fails to account for. ${ }^{5}$ The sources of that heterogeneity could be multifold.

In the past, studies have allowed for the FDI effects of regulation to differ between developed and developing countries (Kheder and Zugravu 2012) and between vertical and horizontal investments (Rezza 2013). It was also put forward that the home country may moderate the effects: Naughton (2014) argues that the strength of PHH effects depends on the stringency of home country regulation and Cai et al. (2016) find that investments in China respond to the toughening environmental regulation depending on whether they come from countries with better environmental protections than China or not. There might also exist differences between industries. Poelhekke and van der Ploeg suggest that in some industries a reputation for sustainable management and corporate social responsibility (CSR) may be more important than avoiding stringent environmental policy and Wagner and Timmins (2009) find evidence in German FDI data for the pollution havens in the chemicals, but not in other polluting industries.

To the best of our knowledge, the literature has not addressed the potential differences in the effects of environmental regulation across the modes of entry. List and Co (2000), List (2001) and Keller and Levinson (2002) could be seen as an exception here. However, the studies List and Co (2000) and List (2001) do not compare the two investment modes, but instead confine themselves to new plant births (Greenfields) for their estimations. Motivated by the intuition that regulatory differences among states should be capitalized into purchase prices, Keller and Levinson (2002) try to identify differences between new and existing plants. Their analysis, however, is severely restricted by the lack of a unified data set for both modes of entry, leading to unexpected discrepancies in the results (see discussion at p. 701).

The differences in empirical results could also be driven by varying approaches to measuring the pollution haven effects: studies look at sales by affiliates, stock and flow of FDI capital, or location decisions. Rezza (2015) carries out a meta-analysis on a sample of 26 publications and finds, among others, that when studies look at the decision to locate individual plants, they are most likely to find the pollution haven effect. This is also the strategy followed in the present paper.

\section{Entry Mode and Environmental Regulation}

When imposing new environmental regulation, legislators also decide whether and to what extent actors that are negatively affected by the new measures receive some form of (transitional) relief. Vintage differentiation rules that condition regulation on the vintage of facilities are a very common form of such a relief. Seminal examples of VDR applications come from the U.S. Clean Air Act and the Clean Water act (cf. Stavins 2006, p. 31).

The so-called grandfathering is one of the applications of VDR. It is present in environmental setback rules that stipulate the minimum distance which a building or other

\footnotetext{
${ }^{5}$ Heterogeneity has also been identified as an important factor that impedes finding evidence for the PHH in trade studies (Levinson and Scott Taylor 2008).
} 
structure must be set back from a river, shore or any other place deemed to need protection. For those rules grandfathering provisions prescribe that if a structure was built before the passage of the regulation, the structure is permitted to be non-compliant as long as it does not undergo any substantial modifications. Consequently, incumbents may enjoy particularly convenient locations that are not accessible to new plants. Grandfathering is also often used for cap-and-trade systems, e.g. in the initial phases of the European Union Emission Trading Scheme the emission allowances were allocated for free based on historic emissions. When it comes to water protection, Germany exempts all industrial facilities built before August 1957 from the need to obtain water usage permits. ${ }^{6}$

VDRs discriminate against new entrants, giving competitive advantage to existing facilities. This can induce multinationals to lean towards M\&As instead of Greenfields when the environmental compliance costs are high enough, possibly even replacing a planned Greenfield investment with a cross-border merger. Therefore, ceteris paribus, investment in form of Greenfield should be chosen less often in countries with higher environmental stringency.

Unfortunately, applications of VDRs have not been systematically studied or catalogued. No cross-country comparisons of the intensity of VDRs exist and, to the best of the authors' knowledge, there is only one cross-country report on their application. In 2013, a survey was run by the OECD among its member countries (Kozluk 2014). The results provide support for pronounced vintage-differentiation and environmental tax/subsidy measures discriminating between entrants and incumbents in all surveyed countries apart from Ireland, the Netherlands, Slovakia, Switzerland, Turkey and UK.

Another channel that favors M\&As in countries with more environmental regulation is the capitalization effect. The price paid for a company will depend on the valuation of the target company. The valuation methods, be it discounted cash flow analysis, merger analysis, comparable companies method or any other accepted methodology, ${ }^{7}$ consider all profitrelevant factors, including the potential effect of environmental regulation. If regulation hinders profits, the regulated company will be available for sale "at a discount" compared to no regulation situation. Thus, the profitability of an M\&A investment will tend to be less affected by regulation than Greenfield where the investment cost is determined mostly by the prices of inputs, wages and construction materials that are used in non-polluting sectors as well.

Empirical confirmation for capitalization effects comes from taxation literature. Hebous et al. (2011) argue that in a high tax country a portion of the tax burden is capitalized. Huizinga et al. (2012) consider the takeover premium paid for international targets and the acquiring-firms' excess stock returns. Their findings are similar and show that additional international taxation is capitalized into takeover premiums implying that the tax incidence falls primarily on target-firm shareholders. Becker and Fuest (2011) make a related argument in their model of tax competition.

\footnotetext{
${ }^{6}$ See $\$ 20$ Wasserhaushaltsgesetz.

7 For the description of valuation methodologies see for instance Petitt and Ferris (2013).
} 
Based on the discussions above we develop a theoretical model of FDI choice. To incorporate the two channels, capitalization effect and VDR effect, the model allows for simultaneous choice of entry mode and location for individual foreign direct investments.

\subsection{Modeling Impacts of Environmental Regulation on FDI Location and Entry Mode}

Suppose that firm $M$ wants to expand its operations and plans to establish a new subsidiary. It needs to choose the investment location and the entry mode, $e$, to maximize the expected profits from the investment. The choice of entry mode determines the vintage, $v$, of the subsidiary, i.e., $v=e=O, N$, where $O$ indicates buying an preexisting (old) firm via M\&A and $N$ denotes a new vintage firm established via Greenfield investment.

Assume that firms in a given sector are identical in all dimensions apart from their productivity and vintage and that productivity is ownership dependent, such that the subsidiary inherits the productivity level of its parent. The productivity of firm $M$, given by $a_{M}$, scales the net present value of operating profits associated with any of the locations. The operating profits of a firm with owner $M$ with vintage $v$ and active in country $c$ can thus be summarized by $a_{M} \pi^{v}\left(\mathbf{X}_{c}\right)$, where $\pi^{v}(\cdot)$ denotes the operating profits function for vintage $v$ and $\mathbf{X}_{c}$ is the vector of country characteristics relevant for profits, such as environmental stringency and GDP.

If $M$ decides to perform a Greenfield investment in country $c$, its operating profits are reduced by the fixed investment costs, $F I X_{c}$, associated with planning, cost to adapt to different labor laws, etc. There may also be idiosyncratic effects related to the profitability of that particular investment. We model those idiosyncrasies through an error term, $\epsilon_{c, M}$, scaling the expected investment profits. In the case of a Greenfield investment, the profit from the investment, $\Pi$, reads:

$$
\Pi_{c}^{M, N}=\left[a_{M} \pi^{N}\left(\mathbf{X}_{c}\right)-F I X_{c}\right] \epsilon_{c, M} .
$$

We can rewrite the fixed costs as $F I X_{c}=F_{c} \pi^{N}\left(\mathbf{X}_{c}\right)$, where $F_{c}$ represents the country-specific share of the standard operating profits that is needed to cover the fixed costs. With this reformulation, the $\log$ of profits of a Greenfield investment in country $c$ is given by:

$$
\ln \Pi_{c}^{M, N}=\ln \left(a_{M}-F_{c}\right)+\ln \pi^{N}\left(\mathbf{X}_{c}\right)+\ln \epsilon_{c, M} .
$$

As an alternative to a Greenfield investment, the parent $M$ could enter country $c$ by acquiring a firm that already operates there (M\&A). Assume that in each country there is one potential investment target denoted by $H$.

In the case of an M\&A, the investment costs are defined by the takeover price which, following Stepanok (2015), we model to be a result of Rubinstein bargaining. This implies that the Nash equilibrium takeover price covers the foregone profits of the target company, which are given by $a_{H_{c}} \pi^{O}\left(\mathbf{X}_{c}\right)$, and a share $\gamma$ of surplus profits created through the takeover, $\left(a_{M}-a_{H_{c}}\right) \pi^{O}\left(\mathbf{X}_{c}\right)$. The profit resulting from an M\&A investment in country $c$ is thus given by

$$
\Pi_{c}^{M, O}=\left[a_{M} \pi^{O}\left(\mathbf{X}_{c}\right)-a_{H_{c}} \pi^{O}\left(\mathbf{X}_{c}\right)-\gamma\left(a_{M}-a_{H_{c}}\right) \pi^{O}\left(\mathbf{X}_{c}\right)\right] \eta_{c, M},
$$

with $\gamma$ reflecting the bargaining power of the incumbents and $\eta_{c, M}$ being an error term, capturing the idiosyncrasies associated with the investment. Taking logs, we arrive at: 


$$
\ln \Pi_{c}^{M, O}=\ln \left[(1-\gamma)\left(a_{M}-a_{H_{c}}\right)\right]+\ln \pi^{O}\left(\mathbf{X}_{c}\right)+\ln \eta_{c, M} .
$$

Combining Equation (1) and (2), a profit associated with investment in country $c$ through entry mode $e$ can be formulated in general form as:

$$
\begin{aligned}
& \ln \Pi_{c}^{M, e}=\ln \pi^{e}\left(\mathbf{X}_{c}\right)+\mathbb{1}_{e=O} \ln \left[(1-\gamma)\left(a_{M}-a_{H_{c}}\right)\right]+\mathbb{1}_{e=N} \ln \left(a_{M}-F_{c, i}\right) \\
& \quad+\mathbb{1}_{e=O} \ln \eta_{c, M}+\mathbb{1}_{e=N} \ln \epsilon_{c, M} \text { for } e=\{O, N\}
\end{aligned}
$$

Whether the investor prefers to invest in country $c$ through Greenfield or M\&A depends, among others, on how attractive the country is for new firms compared to incumbent firms. There are three main elements that make $\pi^{o}$ differ from $\pi^{N}$. First, vintage differentiation in environmental regulation decreases the environmental costs for existing businesses. Second, new businesses often receive tax holidays that relax their tax burden compared to existing companies. Third, new companies might differ in technologies used and organizational structure. To reflect those elements, we assume a Cobb-Douglas functional form of the countries' attractiveness and specify the vintage differences in operating profits as follows:

$$
\ln \pi^{N}\left(\mathbf{X}_{c}\right)=\ln \pi^{O}\left(\mathbf{X}_{c}\right)+\beta_{V D R} e n v_{c}+\beta_{\tau G F} \operatorname{ctax}_{c}+\ln P_{\Delta},
$$

where $\beta_{V D R}$ reflects the cost advantage of VDR provisions, env $v_{c}$ depicts the stringency of environmental regulation in country $c, \beta_{\tau G F}$ captures the effect of a beneficial tax treatment for Greenfield that interacts with the tax rate $\operatorname{ctax}$, and $P_{\Delta}$ represents the systematic differences in level of operating profits that new firms may provide compared to the old ones.

Plugging the relationship (4) into Equation (3) and assuming that the idiosyncratic components for the two investments modes are drawn from the same distribution, we rewrite the generalized investment profit function as

$$
\begin{array}{r}
\ln \Pi_{c}^{M, e}=P+\ln \left(a_{M}-a_{H_{c}}\right)+\ln \pi^{O}\left(\mathbf{X}_{c}\right)+\mathbb{1}_{e=N} \ln \frac{P_{\Delta}}{(1-\gamma)}+\mathbb{1}_{e=N} \ln \frac{a_{M}-F_{c}}{a_{M}-a_{H_{c}}} \\
+\mathbb{1}_{e=N} \beta_{V D R} e n v_{c}+\mathbb{1}_{e=N} \beta_{\tau G F} \operatorname{ctax}{ }_{c}+\zeta_{e, c, M} \text { for } e=\{O, N\},
\end{array}
$$

with $\zeta_{e, c, M}$ denoting the idiosyncratic element and $P$ being a constant equal to $\ln (1-\gamma)$.

For its investment, the firm will choose a country-entry mode combination $\left(c^{*}, e^{*}\right)$ which maximizes investment profits. Formally, $\ln \Pi_{c^{*}}^{M, e^{*}} \geq \ln \Pi_{c}^{M, e} \forall c \in C, e \in\{O, N\}$, where $C$ is the set of countries available for investment. The relative attractiveness of the countries will depend on the mode of investment. For two countries, $A$ and $B$, it is possible to have $\Pi_{A}^{M, O}<\Pi_{B}^{M, N}<\Pi_{B}^{M, O}<\Pi_{A}^{M, N}$. This example illustrates that it would not be optimal for the parent firm to decide on the location in a first step and after that decide on the mode of entry. Likewise, it can lead to a sub-optimal profit to first lock into a certain mode of entry and then decide on location.

We can not observe firms' profits. In the empirical analysis, we use them as a latent, unobservable variable that determines the probability of a particular location and investment mode being chosen. The estimated coefficients for observable variables are thus considered important for the location-entry-mode-specific investment profitability and interpreted as the effect of the variable on the probability that a specific country-mode-of-entry alternative is chosen out of all conceivable alternatives. With profit as an latent, unobservable variable whose value increases the likelihood that the respective country-mode-of-entry alternative is chosen, the structure of Equation (5) lends itself to estimation by logistic regressions in 
which each country-entry mode combination a priorily is a possible choice option. In particular, conditional logit is suitable for estimating parameters in choice structures like ours.

The right hand side (rhs) of Equation (5) informs the choice of explanatory variables in such a logistic regression. While $P$ is a constant, the second term on the rhs indicates that the choice of a country as a location may depend on the productivity of local firms, which can be captured by country dummies. The third term makes clear that the profit level in a country $c$ depends on elements of $\mathbf{X}_{c}$, which may be the stringency of environmental regulation, GDP, the level of corruption, etc. The fourth term is identical for all countries, but differs for Greenfield and M\&A, suggesting a mode of entry dummy. Term five indicates that the profit advantage of Greenfield investments may be country specific. Assuming that $\beta_{V D R}$ is constant across countries, the sixth term suggests an interaction term between the mode of entry and the local level of environmental stringency. Similarly, the seventh term calls for an entry-mode specific tax effect.

Based on Equation (5), we can compare the marginal effects on profit that a change of environmental regulation, $\frac{\partial \Pi_{c}^{M, o}}{\partial e n v_{c}}$ and $\frac{\partial \Pi_{c}^{M, N}}{\partial e n v_{c}}$ has for the two mode of entries:

$$
\frac{\partial \Pi_{c}^{M, N}}{\partial e n v_{c}}=\frac{\partial \Pi_{c}^{M, O}}{\partial e n v_{c}} \frac{P_{\Delta}}{1-\gamma}\left(\frac{a_{M}-F_{c, i}}{a_{M}-a_{H_{c}}}\right) e^{\beta_{V D R} e n v_{c}} e^{\beta_{\tau G F} c t a x} \frac{\zeta_{O, c, M}}{\zeta_{N, c, M}}+\beta_{V D R} \Pi_{c}^{M, N}
$$

The capitalization effect is reflected in the first element of (6). As under the M\&A entry mode, the investor company gets to keep only part of operating profits defined by $(1-\gamma)\left(a_{M}-a_{H_{c}}\right)$. the effect of all variables that affect the investment profit through the operational profit in a given location will be scaled down proportionally. ${ }^{8}$ This is true also for the environmental regulation. The vintage differentiation effect, on the other hand, is visible in the second element in Equation (6) and its magnitude is proportional to the cost savings provided by vintage differentiation, as defined by $\beta_{V D R}$.

Because of the above described effects, the environmental stringency should not only impact the magnitude of FDI flowing to a given country but also the composition of a country's inflowing FDI in terms of share of Greenfield investments. ${ }^{9}$

\section{Identifying the Impact of Environmental Regulation on FDI}

\subsection{FDI Data}

Our empirical application uses data on German outbound FDI. The Microdatabase Direct Investment (MiDi) is gathered by the Deutsche Bundesbank based on the Foreign Trade and Payments Regulation. ${ }^{10}$ Because MiDi contains confidential firm data, its use is subject to restrictions. Notably, the data may be used only at the premises of the Deutsche Bundesbank. $^{11}$

\footnotetext{
${ }^{8}$ The level of profits also differs for the two investment modes because of the organizational differences, captured by $P_{\Delta}$, and because of differences in idiosyncratic terms.

9 A previous, longer version of the paper empirically confirmed this prediction.

10 DOI: 10.12757/Bbk.MiDi.9915.03.04. For a data description see Blank et al. (2020).

11 At these premises, Deutsche Bundesbank may also give data access for replication studies.
} 
MiDi keeps a comprehensive and highly reliable account FDI where the balance sheet total of the foreign affiliate exceeds 3 million euros and the German investor has $10 \%$ or more of voting rights. ${ }^{12}$ The data contain the industry of both the investing and the target company.

Unlike in most other FDI datasets, new investments recorded in MiDi are categorized as Greenfield or M\&A investment.

The entry mode differentiation was first introduced in 2005. In our analysis, we study years 2005-2011, during which 2619 German companies conducted around 9400 new cross-border projects, out of which $39 \%$ took the form of Greenfield investments. ${ }^{13}$ On average, a parent company in our sample performs 3.58 investments. The 10 most active parents executed over 70 cross-border projects, each. Over 1420 parents were observed only once in their choice.

Most of the analyzed projects flowed to the low polluting industries (73\%). Geographically, they concentrated in Europe (62\%) and the Americas (20\%). In total, there are 98 host countries in our sample and $20 \%$ of the projects target developing economies.

It is worth emphasizing that even among developed countries there are substantial differences in environmental protection. For instance, Greece is roughly half as stringent as Denmark and many developing countries like Tunisia or Jordan outmatch Greece in terms of environmental regulation. ${ }^{14}$

A possible concern is that parent firms in developed countries like Germany may have adapted to strict regulation (see Cai et al. 2016 and Chung 2014) and therefore may have a reduced incentive to seek pollution heavens abroad. If true, the effects for source countries with less strict regulations may be more pronounced than those found in the present paper. Greaker and Rosendahl (2008) and Elliott and Zhou (2013) point out that more stringent regulation may also come at an advantage for firms that are either cleaner or strong in pollution abatement technologies. This may also lead to lower measurement of the investment effects of strict regulation.

\subsection{Data on Environmental Stringency and Pollution Intensity}

The measurement of the core variable in our study - environmental stringency of the host economy - has been disputed in the economic literature. Since the publication of Kellenberg (2009), however, most studies on FDI location rely on the indices from the annual

\footnotetext{
12 The average participation share in the data is $88 \%$. More than $75 \%$ of the investments are wholly-owned, only one in ten investors has a share of $50 \%$ or less.

13 We exclude resource dependent industries, such as mining and agriculture, from our study because investments in these industries imply appropriation of a large share of immobile assets, which may blur the distinction between Greenfield and M\&A.

14 The variation in the approach to environmental protection for developed countries is present both in stringency measures prepared by WEF and OECD (see Sect. 4.2 for measures of environmental stringency). See also Kozluk and Garsous (2016) for illustration of spread of environmental stringency among developed countries.
} 
Executive Opinion Survey published by the World Economic Forum (WEF). ${ }^{15}$ The WEF environmental stringency index is created from responses of business executives to the following questions: ${ }^{16}$

1. How would you assess the stringency of your country's environmental regulations?

2. How would you assess the enforcement of environmental regulation in your country?

Both questions can be answered on a seven points scale, ranging from $1=$ very lax to $7=$ among the world's most rigorous. The survey question is thus framed as a relative comparison (regulation in a country in comparison to other countries), and there is no trend to be observed in the mean values of the variable. Furthermore, the standard deviations are also stable over the years (with the exception of 2007).

We interact the policy stringency index with the policy enforcement index as it was done in Kellenberg (2009) and rescale it down by the factor $10 .{ }^{17}$ The newly created environmental index (envI) takes on values between 0.1 and 4.9.

We believe that the WEF data, by measuring the perception of managers, captures well the stringency of environmental regulation that firms take into account when making investment decisions. The reliance on surveys of manager perception is not unique to environmental regulation, but is widely accepted and used when it comes to measures of corruption (Wei 2000). The OECD has argued that its Environmental Policy Stringency indicator, which is derived through the aggregation of information on selected environmental policy instruments, ${ }^{18}$ shows "relatively high and significant correlations with (...) measures of perceived stringency based on survey responses" (Kozluk and Garsous 2016). ${ }^{19}$ Further merits of using the WEF data are discussed thoroughly by Kellenberg (2009). Manderson and Kneller (2011) comment on how the WEF deals with a possible "perception bias". Nevertheless, as one of the robustness checks, we repeat our estimations using an alternative measure, the OECD Environmental Stringency Index (see Sect. 5.1).

A deficiency of the WEF and OECD indices is that they are available at the country level only; environmental stringency, however, may differ on the country-industry level. This shortcoming is shared with all measures of environmental stringency that have been

\footnotetext{
15 To the best of our knowledge, five out of six PHH-studies published after Kellenberg (2009) that work with investment decision across countries, five studies used the World Economic Forum measure (Wagner and Timmins 2009, Manderson and Kneller 2011, Rezza 2013, Chung 2014, Poelhekke and van der Ploeg 2014). Only Kheder and Zugravu (2012) construct their own index using ratified multilateral environmental agreements (MEAs), international non-governmental organizations' members per million of the population, and energy efficiency.

${ }^{16}$ The WEF cooperates with local partners to address a representative sample of business leaders from different kind of firms. While the pool of respondents changes across years, the WEF tries to reach a fraction of $50 \%$ of respondents who also participated in previous surveys.

${ }^{17}$ We multiply the policy stringency and enforcement indicators as they are highly correlated $(r=0.96)$ and a separate inclusion of both would likely lead to multicollinearity. Moreover, we expect a strong complementarity between the stringency of rules and the intensity of enforcement that should best be captured by interacting the indices.

${ }^{18}$ We can not use OECD index in our main specification given that the index is available only for developed countries and BRICS countries.

${ }^{19}$ We cross-checked the WEF index against other potential measures for environmental stringency. For the OECD Environmental Policy Stringency Index, we find a correlation coefficient of $r=0.55$. Conversely, we find almost a zero correlation with the number of MEAs signed - the stringency measure applied in some previous studies. Presumably, the environmental agreements are often related to international politics more than they reflect real environmental policies (for example, small and/or poor countries like Trinidad \& Tobago, Paraguay, Panama, Nicaragua, Mongolia are signatories of most MEAs).
} 
applied when looking at the location choice among many different countries. One attempt to get industry-level measures was undertaken in 2006 by van Soest et al. (2006) who estimate shadow price indicators of environmental stringency. Unfortunately, abatement cost data necessary for the methodology is lacking for most countries in our sample.

Presumably, there is considerable heterogeneity in the response of investments to environmental regulation and disregarding this heterogeneity could substantially blur the results. In particular, pollution intensity should be important for magnitude of responses and therefore needs to be controlled for. As it is not possible with our data to observe the pollution intensiveness of individual projects, we instead classify the sectors to which the projects belong. To classify manufacturing sectors, we used the industry-level pollution abatement investments recorded for year 2009 by Statistisches Bundesamt (2011), scaled down by the sector's total investments. While this differs from Cole and Elliott (2005) who use value added for scaling, as a check, we also computed the ratio of industry-level pollution abatement investments to industry's value added. As the correlation between the two coefficient equals 0.95 , the two measures lead to almost identical outcomes. On average, the pollution abatement investments constituted $6.5 \%$ of the total investment and $1.4 \%$ of the value added.

In the second step, we arranged the sectors according to the ratios and split them into clean and polluting ones ${ }^{20}$, using as the cut-off point the ratio of pollution abatement to total investment of $2 \%$. Within the sectors classified as polluting, the vast majority had ratios of 2.1-5\% and only few sectors, such as recycling, cokeries, and electricity generation had ratio values above 10 . Within the sectors classified as low polluting, the ratios were between $0.1 \%$ and $1.7 \%$.

Binary sector classification, while relatively robust to potential measurement problems, implies that heterogeneous industries get grouped together. At the same time, there may be substantial differences between the industries in their sensitivity towards environmental stringency and channels through which their profits are affected by environmental regulation. For instance, there may be differences between industries that generate pollution while consuming inputs from other sectors (e.g. transportation) and industries which themselves generate pollutants (e.g. chemical sector). Our estimates provide averages across industries and are generally not informative about the effects for individual industries.

One can expect investments in pollution abatement to correlate strongly with the industries' pollution intensities as the room for legal non-compliance in form of paying penalties is limited in Germany. Most of environmental regulation works through companies obtaining permits for construction and operations, whereby permits specify the regulatory requirements. Non-compliance with those requirements results in withdrawal of the permit. Moreover, an illicit operation of installations requiring an environmental permit might lead to criminal law sanctions for the individuals acting on behalf of a company or owner of the business. $^{21}$

\footnotetext{
${ }^{20}$ In previous versions of the paper (that used a slightly different estimation strategy) we classified projects into clean, medium polluting and high polluting. However, the coefficients for the last two groups were usually almost identical. As the additional distinction strongly increases the number of coefficients to be estimated, decreasing the power of the study, while not adding new insights, we switched to a binary measure of pollution dirtiness.

21 See Federal Pollution Control Act (BImSchG) and information gathered at https://gettingthedealthrough. com/area/13/jurisdiction/11/environment-germany/.
} 
A potential issue with our classification method is that industry-specific pollution abatement costs could reflect lobbying efforts or preference of German authorities for particular sectors rather than the real pollution-content of the economic activities. A sector could have very low relative pollution abatement costs either because it produces no pollution or due to the preferential treatment it enjoys. To address such a concern, we crosscheck the resulting classification against computations obtained from the analog U.S. data (U.S. Census Bureau 2005), and find no significant differences in the thus obtained ranking of industries.

For services, the classification relies on the data gathered by Levinson (2010). The final split of the industries is presented in "Appendix" A. Table 1 presents the number of projects conducted for individual entry-modes types (dirty vs. clean) combination and the number of parent companies that engaged in those projects.

As we theorize, the VDR rules moderate the impact of environmental regulation on M\&A investments. However, as explained in Sect. 3, no measure of strength of VDR rules exist yet and constructing an appropriate index would go beyond the scope of this study given the challenges associated with such an index. ${ }^{22}$ We therefore rely on the assumption that there are no systematic differences in vintage differentiation between countries and sectors.

We hypothesize that highly regulated countries discourage new investments in polluting industries, particularly in the case of Greenfield projects. Consequently, highly regulated countries should receive a disproportionately low share of dirty Greenfield investments. Indeed, data on the composition of cross-border projects across countries is in line with this expectation and Fig. 1 summarizes some of that data by showing all new FDI projects for 15 main host countries for German FDI in the period 2005 to 2011 . $^{23}$ While China, for example, receives only a small share of clean projects, it is a major host for dirty investments, particularly Greenfield investments. For more highly regulated countries, such as France, the proportions are reversed.

The next section attempts to systematically analyze the effect of regulation on Greenfield and M\&A projects using microdata.

\subsection{Analysis of Firm-Level Investment}

Building on the theoretical framework derived in Sect. 3.1, we turn to estimating discrete choice models to understand investment decisions made by German investors. As firms simultaneously decide about the entry mode and investment location, we define the choice options to be country-entry mode pairs, e.g. France-M\&A, France-Greenfield, GreeceM\&A, Greece-Greenfield, etc. This definition of choice sets allows us to bridge two strands

\footnotetext{
${ }^{22}$ Firstly, as VDR tend to apply to some but not all environmental requirements, identifying all relevant exceptions for existing facilities would require in-depth knowledge of the whole environmental regulation system for all analyzed countries. Secondly, even within one jurisdiction, VDR differ in the time period for which they grant the incumbents the transitional relief. Thirdly, they might also differ in the relative stringency of rules applying to incumbents as compared to rules for new entrants, not only between legislative acts but also between pollutants regulated in a given legislative act. Therefore, measuring the strength of VDR could not be boiled down to simple counting of occurrences of vintage-based exceptions.

23 As we rely on confidential data, the output is suppressed whenever less than four German parent companies are used for its calculation.
} 
Table 1 Number of investments and parent firms for different types of investments

\begin{tabular}{llll}
\hline M\&A & No. of investments & $\begin{array}{l}\text { Clean } \\
4013\end{array}$ & $\begin{array}{l}\text { Dirty } \\
1753\end{array}$ \\
\hline \multirow{3}{*}{ Greenfield } & No. of parents & 1246 & 626 \\
& No. of investments & 2933 & 705 \\
& No. of parents & 1241 & 411 \\
\hline
\end{tabular}

Source: Deutsche Bundesbank, Microdatabase Direct Investments (MiDi) 2005-2011, own calculations

of FDI research that were, to the best of our knowledge, so far considered separately: entry mode choice ${ }^{24}$ and location choice. ${ }^{25}$

Given the data availability and the fixed effects interactions, the investor selects among around 90 countries and two entry modes: Greenfield or M\&A, which results in some 180 country-entry mode pairs. ${ }^{26}$ To reflect that choice set, we augment our MiDi data set by generating 179 non-investments for every investment that we see conducted. Conditional logistic regression is well suited for the case when the number of possible choices is large and helps avoid "sparse-data" biases that can arise in ordinary logistic regression (or linear probability model) analysis. ${ }^{27}$ Thus, we make it our primary specification.

The equation guiding our estimation is given by (5). For some of the elements included in that expression there is no data available. In particular, the fixed costs parameters, $F_{c, i}$ the productivity of the target companies, $a_{H_{c}}$ and the bargaining parameter, $\gamma$, are unknown to us. However, they can be replaced by various (interactions) of fixed effects.

For the choice of specification for operational profits function, $\ln \pi_{i}^{v}$, we draw on the PHH-FDI literature and, in addition to environmental regulation, use the following control variables: corporate tax rates (ctax), logarithm of GDP per capita $(g d p)$, logarithm of population (population), the Heritage Foundation index of corruption freedom (corrupt_freedom) and labor freedom (labor_freedom), and openness (openness) measured as ratio of summed imports and exports over the country's GDP. FDIstock is measuring the value of the stock of the inward FDIs for a given country (data taken from UNCTAD) and its purpose is to proxy the factor endowments and the agglomeration effects as suggested by Wagner and Timmins (2009). We also include country fixed effects.

Consequently, the derived log-profits look as follows:

\footnotetext{
${ }^{24}$ See, among others, Nocke and Yeaple (2008), Perez-Saiz (2015) and Davies et al. (2018) for a short review of the relevant studies.

25 See Kheder and Zugravu (2012), Fredriksson et al. (2003), Manderson and Kneller (Jul 2011) and Barrios et al. (2012).

26 The set of potential locations has been determined by the availability of the environmental stringency index and other covariates. With the resulting collection of countries we cover $96 \%$ of the investments undertaken by German investors. We are missing mostly investments that could be purely tax-motivated, such as those to Cayman Islands, Isle of Man, Guernsey, Jersey, Bermuda and British Virgin Islands. However, as explained in Sect. 4.4, due to the interacted fixed effects we exclude from the choice sets countryentry mode combinations that never receive any investments.

27 For the discussion of the problem see Greenland et al. (2000).
} 

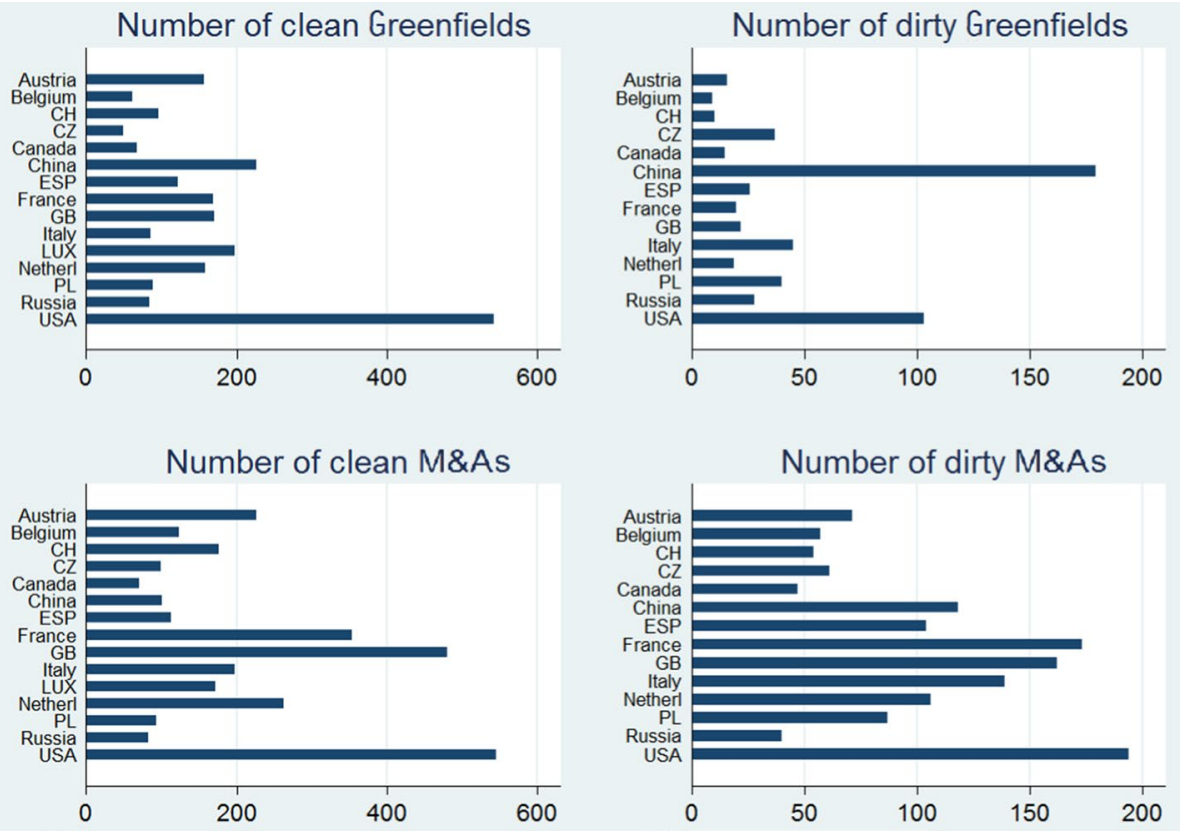

Fig. 1 Structure of investments flowing into major host economies. Source: Deutsche Bundesbank, Microdatabase Direct Investments (MiDi) 2005-2011, own calculations. CH: Switzerland, CZ: Czech Republic; ESP: Spain; GB: Great Britain; LUX: Luxembourg; PL: Poland

$$
\begin{aligned}
\ln \Pi_{c, t}^{M, e}= & \alpha+a_{M} \alpha_{c}+\alpha_{c}+\beta_{\text {env }} \text { env }_{c, t}+\beta_{1} \text { ctax }_{c, t}+\beta_{2} \text { gdp }_{c, t} \\
& +\beta_{3} \text { population }_{c, t}+\beta_{4} \text { corrupt_freedom }_{c, t}+\beta_{5} \text { labor_freedom }_{c, t} \\
& +\beta_{6} \text { openness }_{c, t}+\beta_{7} \text { FDIstock }_{c, t} \\
& +\mathbb{1}_{e=N}\left(\alpha_{G F}+\alpha_{G F} a_{M} \alpha_{c}+\beta_{V D R} \text { env }_{c, t}+\beta_{\tau G F} \text { ctax }_{c, t}\right)+\zeta_{e, c, M},
\end{aligned}
$$

with $\alpha$ being a constant, $\alpha_{c}$ denoting the country fixed effects, $a_{M}$ the productivity of parent company and $\alpha_{G F}$ the Greenfield fixed effect.

While the MiDi-FDI data set contains rich information on the investments in foreign subsidiaries, the investor data is limited to legal form, economic sector, turnover, balance sheet total, and the number of employees. Given these data limitations, we proxy the parent's productivity using two ratios: turnover to balance sheet total and turnover to number of employees. $^{28}$

However, as the data on either turnover or number of employees is missing for almost half of the parents, using the parent productivity measure substantially narrows our sample in a possibly non-random manner. This, combined with very high number of fixed effects leads to convergence problems for our preferred method of estimation: conditional

\footnotetext{
28 As there may be major differences between industries in how costly it is to produce output or to what extent outsourcing is used, we standardize the values within the NACE sector code. In the next step, we take the average of the two ratios in order to avoid collinearity problems.
} 
logit. Based on logit estimations, it also seems that inclusion of parent's productivity does not change the estimates of interests (see estimation results in Sect. 5.3), which could be explained by the investors productivities being orthogonal to other regression variables that are measured on the country level. Additionally, FDI parents tend to be the most successful companies, characterized by productiveness higher than their peers who do not invest abroad (Nocke and Yeaple 2008). Therefore, in our sample there is probably relatively little variability of productivity. For these reasons, our main specifications does not include a measure of parent's productivity but we introduce additional robustness checks for the available subsample below.

The descriptive statistics of the explanatory variables, together with the data sources, are given in Table 2 .

The specified estimation equation reflects the model from Sect. 3.1. However, in our estimations we also include additional elements that could be relevant as well.

One of such factors is the effect of financial crisis on the entry mode choice. As our sample covers years 2005-2011, the financial crisis could have affected the availability of target companies, even though the share of Greenfield projects has been stable over the years (see Fig. 2). To preempt that potential issue, we replace the non-interacted Greenfield dummy $\alpha_{G F}$ with set of year-Greenfield dummies $\left(\mathbb{1}_{e=N, t=2005} \alpha_{G F, 2005}, \mathbb{1}_{e=N, t=2006} \alpha_{G F, 2006}\right.$ etc.). Given that we investigate the location choice, ${ }^{29}$ these Greenfield-specific year fixed effects control for the possibly confounding effect of the financial crisis as long as its impact on FDI determinants is uniform across host countries. ${ }^{30}$

Additionally, the model does not differentiate between sectors, while one can rationally expect the polluting sectors to be more likely to be affected by green regulation than clean ones. To account for those differences, we interact the environmental stringency with pollution intensiveness of the sector. As explained in Sect. 4.2, the sectors, $i$, are classified as clean $(n p)$ or polluting $(p)$. Therefore, we replace $\beta_{e n v} e n v$ and $\mathbb{1}_{e=O} \beta_{V D R} e n v$ in Equation (7) with environmental regulation-entry-mode-pollution-intensity interaction terms: $\mathbb{1}_{e=O, i=n p} \beta_{o, n p}$ env, $\mathbb{1}_{e=O, i=p} \beta_{O, p}$ env, $\mathbb{1}_{e=N, i=n p} \beta_{N, n p}$ env $v_{c}$ and $\mathbb{1}_{e=N, i=p} \beta_{N, p}$ env.

Summarizing, the profits associated with company $M$ investing in sector $i$ in country $c$ through investment mode $e$ in year $t$ are specified as:

$$
\begin{aligned}
\ln \Pi_{c, i, t}^{M, e}= & \alpha+\mathbb{1}_{e=o, i=n p} \beta_{o, n p} \text { env }_{c, t}+\mathbb{1}_{e=o, i=p} \beta_{o, p} \text { env }_{c, t} \\
& +\mathbb{1}_{e=N, i=n p} \beta_{N, c} \text { env }_{c, t}+\mathbb{1}_{e=N, i=p} \beta_{N, p} \text { env }_{c, t} \\
& +\mathbb{1}_{e=N, t=2005} \alpha_{G F, 2005}+\mathbb{1}_{e=N, t=2006} \alpha_{G F, 2006}+\ldots \\
& +\alpha_{c}+\beta_{1} \text { ctax }_{c, t}+\beta_{2} \text { gdp }_{c, t}+\beta_{3} \text { population }_{c, t} \\
& +\beta_{4} \text { corrupt_freedom }_{c, t}+\beta_{5} \text { labor_freedom }_{c, t}+\beta_{6} \text { openness }_{c, t}+\beta_{7} \text { FDIstock }_{c, t} \\
& +\mathbb{1}_{e=N}\left(\alpha_{G F} \alpha_{c}+\beta_{V D R} \text { env }_{c, t}+\beta_{\tau G F} \text { ctax }_{c, t}\right)+\zeta_{e, c, M},
\end{aligned}
$$

It is worth emphasizing that the estimation strategy that we derive is much richer in fixed effects than most other location choice studies. The fixed effects also absorb a host of potential problems with identification. For instance, if some countries tend to restrict inflowing FDI or push the FDI towards a particular entry mode through differences in legal

\footnotetext{
29 The location choice is conditional on the positive investment decision. The decline in the number of cross-border investments in the years of financial crisis (visible in Fig. 2) has thus no effect on our identification.

30 The choice set to consist of all potential entry mode-location combinations in the same year. This implies that we cannot (and need not) include simple time-fixed effects.
} 
Table 2 Descriptive statistics of explanatory variables

\begin{tabular}{llllll}
\hline Variable & Mean & Std. dev. & Min & Max & Source \\
\hline Environmental index & 1.7 & 0.89 & .25 & 4.25 & WEF \\
Corporate tax & 29.16 & 7.5 & 0 & 55 & PWC, Deloitte, Ernst + Young \\
Openness & .72 & .55 & .1 & 4.19 & Penn tables \\
Freedom from corruption & 52,68 & 16,06 & 14 & 97 & Heritage foundation \\
Labor freedom & 69.46 & 16.08 & 27 & 100 & Heritage foundation \\
Log of FDI stock & 10.03 & 1.97 & 4.64 & 15.08 & UNCTAD \\
Log of population & 2.61 & 1.65 & -1.29 & 7.21 & Penn tables \\
Log of GDP per capita & 9.46 & 1.11 & 6.57 & 11,91 & Penn tables \\
Log of distance & 8.22 & 1.04 & 5.15 & 9.84 & CEPII \\
Log market capitaliz. & 4.15 & 1.85 & -2.3 & 7.134 & World Bank \\
OECD environmental index & 2.2 & .92 & .38 & 4.13 & OECD \\
\hline
\end{tabular}

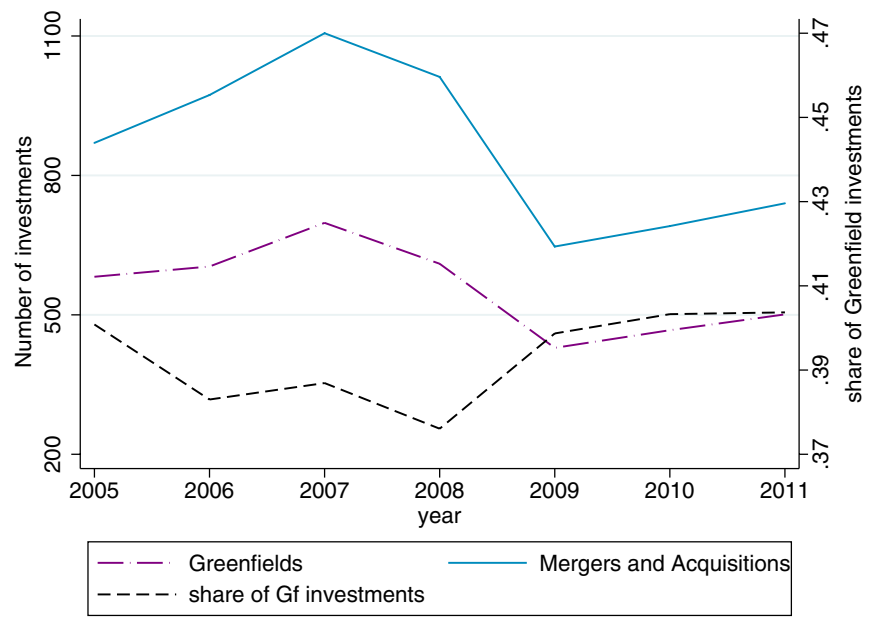

Fig. 2 Relative and absolute number of German outward FDI projects over the years. Source: Deutsche Bundesbank, Microdatabase Direct Investments (MiDi) 2005-2011, own calculations

treatment, we will be able to control for it as we allow the unobserved country characteristics to be different across Greenfield and M\&As. Ideally, we would use triple-interacted fixed effects, allowing additionally for differences between clean and polluting industries within a given country for given entry mode. Those would control for the possibility that in 
some countries the distribution of potential target companies for M\&A may be asymmetric between the clean and polluting sectors. ${ }^{31}$ Unfortunately, such an approach requires estimation of approximately 350 fixed effects, which turns out to be computationally difficult for conditional logit and leads to convergence problems. We therefore keep the double-interacted fixed effects with conditional logit as our default specification and estimate a tripleinteracted fixed effects logit regression as a robustness check in Sect. 5.4.

Our default fixed effects approach should lead to the same results as the fully-fledged fixed effects strategy as long as any preexisting differences in M\&A propensity between clean and dirty sectors are orthogonal to environmental regulation. Consequently, there are two possible cases when our default estimation strategy would lead to biased inference on the effects of environmental regulation.

First, it is possible that high past levels of environmental stringency reduce the propensity of performing M\&As in dirty industries today by reducing the number of possible takeover targets. If countries with high past levels of stringency had a clear and uniform trend in the development of environmental rules, our reliance on variation within individual countries could mean our estimations of the coefficient of environmental stringency variable are contaminated. However, we do not find such a trend. ${ }^{32}$ This may be partly due to the construction of the index, which asks respondents to compare a country relative to the most regulated ones.

Second, an omitted variable bias could cloud our default results. In particular, our findings on differences between entry modes would be misguided if our model in Sect. 3.1 overlooked a factor that affects the environmental regulation and impacts the propensity for M\&A type of investments asymmetrically for clean versus polluting industries. However, the existence of such a factor is far from trivial. Nevertheless, to make sure that the potential sources of bias described above do not contaminate our study, we check the robustness of our findings employing a control function (CF) approach to instrument the environmental regulation. We delegate this robustness check to Sect. 5.5.

As our estimations always include country-entry mode fixed effects, identification comes from changes in propensity to invest in a given location with a given entry mode. Our assumption is that if we observe a clean investment in one country, the investment would have been a clean investment also if carried out in alternative countries, i.e. that the investment's sector is predetermined. Hence, the dummies for clean and dirty industries do not vary within choice sets and are not included in the regressions.

\subsection{Firm-Level Data: Empirical Results}

Table 3 presents the estimation results for the main specification described in Sect. 4.3 (column I), and its two modifications (columns II and III) .

In specifying the differences in operating profits between the vintages in Equation (4), we assume that only environmental regulation and corporate taxation affect the entry modes differently. However, it is conceivable that other variables have distinct effects as

\footnotetext{
${ }^{31}$ For example, polluting industries could be more mature and thus provide more potential takeover targets.

32 We define countries to be initially highly regulated if they exhibit stringency above a certain threshold in the first year that we observe them. For the case when the threshold is defined as average initial environmental regulation, the median country increases its stringency by 0.39 (from around 2.25). For threshold value 3 (which defines $10 \%$ of the initially most stringent counties), the median country increases its regulation by 0.14 .
} 
well. ${ }^{33}$ Therefore, in specification (II) we allow the effect of all variables to depend on the entry mode. The only variable that significantly affects the likelihood of Greenfield investments is the preexisting stock of foreign direct investment in the respective country, which suggests that Greenfield investments benefit from prior experience of (other) foreign investors.

In specification (III) we address the problem of potential contamination of the entry modes estimates through financial crisis. If the number of target companies changes over time within a given country and that change is caused by some characteristic that is not controlled for, but correlates with environmental regulation, our inference about the differences between entry mode would be misguided. To address that possibility, we proxy for availability of target companies using market capitalization data from World Bank and interact it with the entry mode (MA\#market_capit). The results presented in column (III) indicate that market capitalization is not a significant predictor of the FDI decision, suggesting that the financial crisis does not drive the results.

Due to our extensive fixed effects strategy, the estimates of most of the country-level explanatory variables used in the literature are not significant.

At the same time, the environmental coefficients exhibit the hypothesized patterns in all specifications: higher environmental stringency is associated with significantly fewer dirty Greenfields. While for dirty M\&As this effect holds as well, it is smaller and less significant. The difference between the M\&A and Greenfield coefficients is statistically significant at the $1 \%$ level as shown by the results of the Wald test reported in the table as "test dirty".

This suggests that stringent environmental regulation may be causing substitution between entry modes in polluting sectors: if stricter green regulation prevents a Greenfield investment, a firm may want to perform an M\&A project instead, if convenient target companies exist and legal rules or capitalization effects favor M\&As.

The location of clean Greenfield projects seems unrelated to environmental stringency. For clean M\&As, on the other hand, we find a weakly positive relationship. This may be due to the "green haven effect" reported by Poelhekke and van der Ploeg (2014): firms that seek to appeal to environmentally-aware consumers and maintain a sustainable image may decide against settling in low regulated regions to prevent potential reputation losses. ${ }^{34}$ When costs of compliance with environmental regulation are relatively low (and they will be for firms in clean sector) and when entering by M\&A can further dilutes any environmentally-related costs, this image boosting may be a profitable strategy. However, we find less support for the importance of the entry mode as the value of the Wald test ("test clean") varies strongly across specifications. This is congruent with the arguments that the lower the costs of compliance with the regulations, the lower both the impact of those regulations and the relative disadvantage of Greenfield type of entry.

\footnotetext{
33 For instance, the importance of corruption may depend on the network that a company has access to and it will tend to be higher for incumbents than for new entrants.

34 Germany, due to its strong organic market and large investment in renewable power, should have a strong base of environmentally aware consumers. According to Sustainability Consumer Trends Database provided by Natural Marketing Institute (see LOHAS Database at http://www.nmisolutions.com), Germans, when compared to their peer consumers in other countries, are more engaged in the environmental and sustainable movements. Importantly, German consumers search for information regarding the environmental quality of the products. While not all of the German MNEs supply final consumers in Germany, for a significant fraction of companies, this may be a relevant consideration.
} 
Table 3 Coefficients from conditional logit estimations

\begin{tabular}{|c|c|c|c|}
\hline & I & II & III \\
\hline gf \# dirty \# envir & $-.677 * * *$ & $-.693 * * *$ & $-.736 * * *$ \\
\hline gf \# clean \# envir & .019 & .003 & .005 \\
\hline MA \# dirty \# envir & $-.198^{*}$ & $-.181^{*}$ & $-.281 * *$ \\
\hline MA \# clean \# envir & $.182 * *$ & $.199 * *$ & .129 \\
\hline $\operatorname{ctax}$ & -.02 & -.023 & $-.027 * * *$ \\
\hline gf \# ctax & -.012 & -.006 & -.021 \\
\hline corrupt_freedom & .004 & .004 & -.001 \\
\hline labor_freedom & $-.016^{* * *}$ & $-.013^{* *}$ & $-.02 * * *$ \\
\hline population & 1.07 & 679 & 1.575 \\
\hline gdpPerCap & -.365 & -.058 & -.521 \\
\hline openness & .065 & -.083 & .098 \\
\hline FDI_stock & .149 & -.058 & .157 \\
\hline gf \# corr_freedom & & -.001 & \\
\hline gf \# labor_freedom & & -.004 & \\
\hline gf \# population & & .451 & \\
\hline gf\# gdpPerCap & & .12 & \\
\hline gf \# openness & & .287 & \\
\hline gf \# FDI_stock & & $.497 * *$ & \\
\hline market_capit & & & .001 \\
\hline MA \# market_capit & & & .001 \\
\hline country\# entry mode FE & $\mathrm{x}$ & $\mathrm{x}$ & $\mathrm{x}$ \\
\hline year\# Greenfield FE & $\mathrm{x}$ & $\mathrm{x}$ & $\mathrm{x}$ \\
\hline test dirty & $* * *$ & $* * *$ & $* * *$ \\
\hline test clean & & $*$ & \\
\hline No. observ (in thsd.) & 1594 & 1594 & 950.8 \\
\hline Log pseudolik. & -38633 & -38624 & -31273 \\
\hline
\end{tabular}

Note: The response variable is a dummy equal to one for the country-entry-mode combinations chosen by a German parent for an FDI project.. Year-Greenfield fixed effects and country-entry mode fixed effects are included in all specifications. Standard errors are clustered at the investor level. *** significance at $1 \%$ level, ** 5\% level, * $10 \%$ level. Results report coefficients rather than odds ratios. Source: Deutsche Bundesbank, Microdatabase Direct Investments (MiDi) 2005-2011, own calculations

\section{Robustness Checks}

In this section, we report robustness checks that address six potential concerns with our preferred specification given in column (I) of Table 3. The checks confirm robustness of our main results.

First, we study whether our results hinge on the way we measure environmental regulation. Second, we check whether our findings could be driven by inclusion of services in our sample or by heterogeneities across industries. Third, we address the potential influence that firm characteristics may have on the entry mode and the interpretation of our results. In the fourth check, we introduce additional fixed effects to investigate whether systematic 


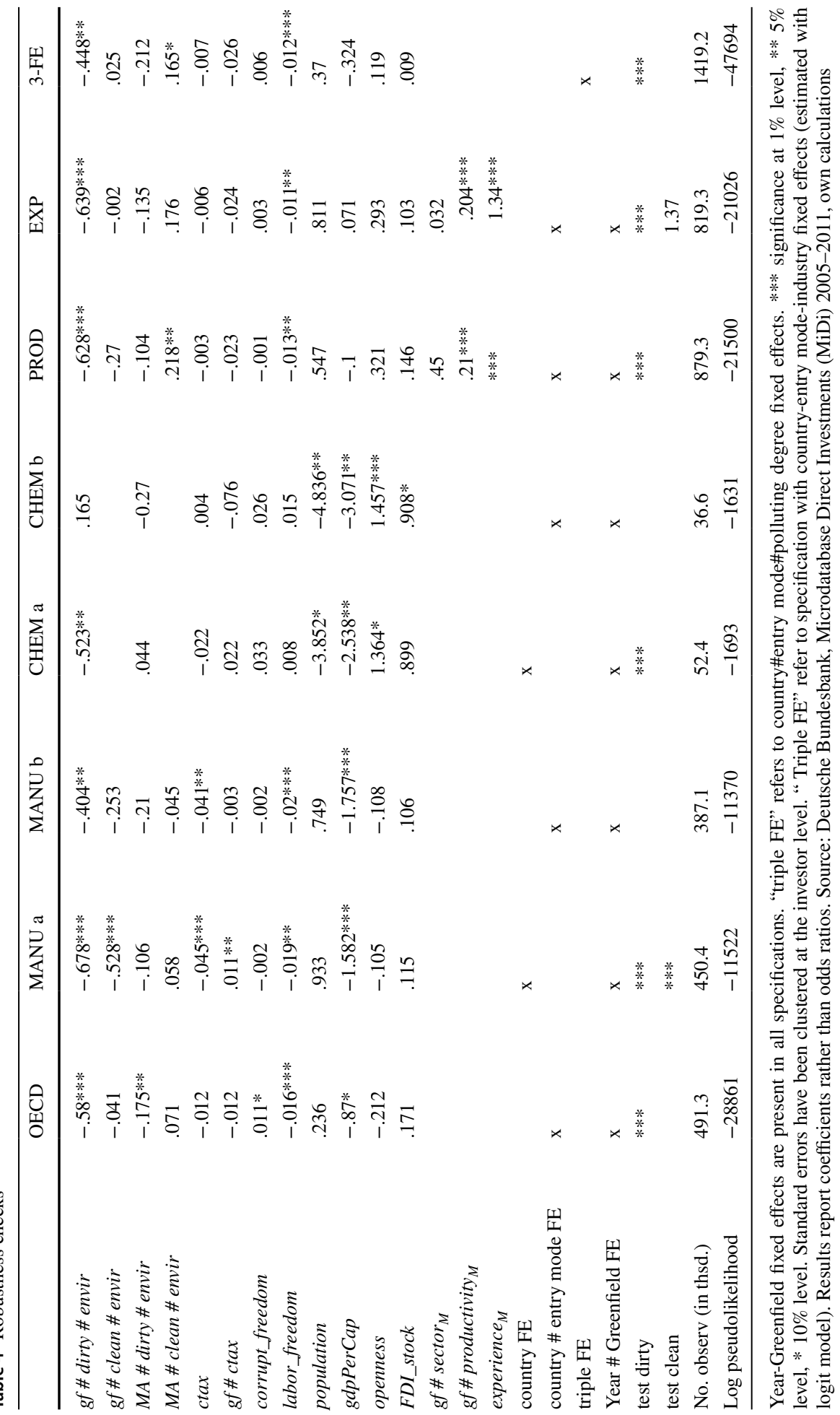


differences between clean and polluting industries within individual countries could be confounding our results. Finally, we check the importance of the independence of irrelevant alternatives (IIA) assumption imposed by the choice of a conditional logit model, while enhancing the estimations by using instrumental variables to deal with the potential endogeneity of environmental regulation.

\subsection{Measuring Environmental Regulation}

The difficulty of measuring environmental stringency has been seen as a potential reason for the heterogeneous $\mathrm{PHH}$ results in the past. To assure that our findings are not driven by some particular feature of the WEF index, we repeat our estimations using the OECD measure of environmental regulation. The index is based on the degree of stringency of 14 environmental policy instruments, primarily related to climate and air pollution, covering 28 OECD and 6 BRIICS countries. ${ }^{35}$ The index uses prices of market-based instruments (taxes, etc.) to measure the economic costs of regulation.

The narrow country coverage constitutes a drawback of the measure. ${ }^{36}$ The OECD measure also does not represent decision makers' views, but rather is constructed by OECD staff using weights for different dimensions of regulation. At the same time, the measure explicitly accounts for regulatory costs that a new, representative plant would need to bear in a polluting industry, making it a reliable proxy for environmental regulation.

The OECD specification in the first column of Table 4 reports the coefficients of interest for the regression where the WEF environmental index from setup (I) from Table 3 was replaced by the OECD index. As with the WEF measure, the environmental stringency coefficient is more negative and more significant for polluting Greenfield than for M\&A investments. The two modes of entry exhibit significant differences in their reactions to environmental policies as indicated by the "test dirty" statistic. For both types of clean FDI, though, more stringent environmental regulation is not associated with changes in the propensity to invest. Unlike in some specifications of Table 3 , we do not find a statistically significant allurement effect of highly regulated countries for clean M\&As.

\subsection{Pooling of Various Industries}

It has been claimed, among others by Kheder and Zugravu (2012), that all industries should have an interest in avoiding additional costs induced by stricter environmental regulation as there are no totally "clean" industries. Such statements were made mostly in publications which investigated the manufacturing sectors only. The fact that our results indicate that stringency of environmental regulation has either no effect or a slightly positive effect on the location decisions of clean projects could thus be driven by the inclusion of services in our sample. ${ }^{37}$ To check whether this is indeed the reason, we reestimate our models using manufacturing projects only.

Even when we omit services investments, heterogeneities between manufacturing industries could blur the results. As pointed out in a trade context by Ederington et al. (2005),

\footnotetext{
35 For the methodology behind the OECD measure, see Botta and Kozluk (2014).

36 However, because the majority of German FDI flows to developed countries, we lose only around $20 \%$ of the conducted investment projects.

37 In our sample, investment in services account for over $75 \%$ of the clean M\&As.
} 
some industries may not be prone to regulation-induced migration at all. Indeed, Wagner and Timmins (2009), when analyzing German FDI flows, find evidence of a pollution haven effect only for the chemical FDI, but not for wood pulp and paper, primary metals, and some others.

Therefore, to check whether the differences between entry modes hold even for the dirtiest industries, we repeat the analysis relying exclusively on chemical projects. This is a natural choice given the conclusions from Wagner and Timmins (2009) and the large share of environmental costs in the total cost for that particular industry (Ederington et al. 2005). Importantly, it is also a German business line relatively active internationally compared to other polluting cross-border projects: there were 452 chemical investments performed in 59 different countries in years $2005-2011^{38}$ compared to, for example, fewer than 50 projects in manufacturing of pulp, paper and paper products or some 240 projects in basic metals and fabricated metal products.

However, restricting our attention to particular investment groups in combination with our fixed effect strategy (country-entry mode fixed effects) leads to a significant loss of alternatives available in the choice sets and thus to potential selection problems. ${ }^{39}$ To get a broader picture of the problem, we report in Table 4 specifications with country fixed effects (columns MANU a and CHEM a) ${ }^{40}$ in addition to country-entry mode fixed effects specifications (columns MANU b and CHEM b). Since all investments in chemical industry are classified as polluting, the coefficients for clean investments ( $g f$ \# clean \#envir and MA \# clean \#envir) cannot be estimated.

Not surprisingly, the estimation results from the MANU b and CHEM b specifications return less significant results than the specifications MANU a and CHEM a that are allowed to exploit a larger fraction of the variation in the data. In general, we do not find support for a negative effect of environmental regulation on the location of M\&As. The results yield support for differences between the modes of entry (test dirty and test clean statistics) as long as country-entry mode fixed effects are excluded.

The sign of most control variables is not consistent across our various robustness checks. GDP per capita enters negatively, which is not unusual in FDI regressions and may reflect higher wage levels in high income countries.

\subsection{Individual Firm Characteristics}

As explained in Sect. 4.3, the above analysis has concentrated on how country-level variables affect investment decisions. However, our model and the literature on entry mode point to productivity of the parent company as one of the decisive factors for the investment assessment, with more productive firms leaning towards Greenfield investments (Nocke and Yeaple 2008, Stepanok 2015). A simple test of whether the parent characteristics affect the results interacts the productivity of the parent with the Greenfield dummy $\left(\right.$ gf\#productivity ${ }_{M}$ ). Given that the parent's experience in a given industry (and the relevant

\footnotetext{
38 Around $25 \%$ of those investments were Greenfields (undertaken by 46 different parent companies). M\&As were performed by 108 parents. Approximately $35 \%$ of the investments were located in Europe (including Russia), 30\% targeted China and some $20 \%$ were conducted in the US.

${ }^{39}$ For example, chemical Greenfield FDIs were conducted in 27 countries only. As fixed effects can be identified only for locations that received real investments, the econometric model allows the companies to choose the location for their potential Greenfield investments only out of those 27 countries.

40 Those are to be compared with column (II) in Table 3 .
} 
know-how) also has been named as a factor influencing entry mode choice, we generate a dummy that takes value 1 if the parent is active in the same sector as the newly created subsidiary and interact it with Greenfield dummy, gf\#sector ${ }_{M}$. The results of the respective conditional logit estimation are presented in column (PROD) in Table 4.

We find indication of most efficient firms performing Greenfield projects (attested by positive and significant gf\#productivity ${ }_{M}$ coefficient) but parent's experience in the sector does not appear to influence the entry-mode choice. Importantly, inclusion of the firm characteristics leaves the other estimates unaffected, both in terms of magnitudes and significance levels. Only the environmental estimate for dirty M\&As shrinks and loses its statistical significance (in previous analyses it was significant at the $10 \%$ level).

We thus corroborate the hypothesis that individual firm characteristics matter strongly for the entry-mode choice. Nevertheless, we find no systematic relationship between them and country characteristics that would distort our main results.

A factor that may also influence the decision on the mode of new entries is whether the parent has already established presence in a respective country. Column EXP of Table 4 therefore adds a variable experience ${ }_{M}$. Although this variable is significant and positive, our main variables of interest behave as in the baseline regression. ${ }^{41}$

In case of a sorting among companies, a correlation between firm and host country characteristics could also bias our results. ${ }^{42}$

To account for a possible interaction between firm and host country characteristics Equation (7) suggests using a full set of productivity interactions. However, with the productivity measure being available only for a subset of parents, thus decreasing our sample substantially, we are unable to run conditional logit and turn to logit estimations instead. The results are presented in Table 5. By comparing the column A with $\mathrm{B}$, and $\mathrm{C}$ with $\mathrm{D}$ (specifications with and without the individual productivity measure interactions) we see that the parent productivity does not affect the estimates, in particular it leaves the magnitude and significance of the environmental stringency coefficient unaffected.

\subsection{Choice of Fixed Effects Strategy}

Our preferred specification uses country-entry mode fixed effects (interaction of the country fixed effects with a Greenfield dummy) but given our research question we would ideally allow for differences between clean and polluting industries within a particular country for given entry mode as well. Assume for example, that in many countries the polluting sectors are, in contrast to clean sectors, underdeveloped. In such a case the coefficient on polluting M\&As may be capturing the unavailability of target companies, not the influence of environmental stringency per se. With country-entry mode-polluting industry fixed effects we would exclude the possibility of such confounding effects. We could also control in a cleaner manner for the possibility of dirty industries being attracted to locations with higher capital endowment as posited by the factor-endowment hypothesis (Eskeland and Harrison 2003, Cole and Elliott 2005).

\footnotetext{
41 Because the variable experience has the flavor of a lagged dependent variable, we consider this a robustness check and do not enter it into our baseline regression.

42 For example, if the most productive firms tend to invest in the least developed markets (which usually are the least regulated in terms of environmental protection) and at the same time tend to perform Greenfield investments.
} 
Given that possibility of cleaner identification of the effects, we implement triple-interacted fixed effects. However, using such complex fixed effects requires estimation of well over 350 coefficients, which leads to convergence problems in the conditional logit framework (see the discussion in Sect. 4.3). Therefore, for the triple fixed effects estimations, we simplify the econometric approach by relying on logit regressions.

As shown in column 3-FE in Table 4, the additional controls do not change the magnitude of our coefficients of interest but only mildly decrease their statistical significance. This suggests there are no systematic differences between clean and dirty investments within the individual countries that confound our inference.

\subsection{Independence of Irrelevant Alternatives and Endogeneity of Environmental Stringency}

A potential problem with conditional logit is its reliance on the underlying independence of irrelevant alternatives (IIA) assumption. The IIA implies that if one alternative became unavailable, the probability of all other alternatives to be chosen would increase proportionally. Nested logit overcomes to some extent the problem of rigid substitution patterns and could thus be used to check whether our findings are an artifact of the IIA assumption. However, given that nested logit requires the researcher to identify the nests which are open to subjectivity, we estimate a mixed logit model instead.

Mixed logit (also known as random-parameters logit) generalizes conditional logit (and nested logit) by allowing "taste variations" among decision makers. It allows the researcher to control for the fact that companies may attach different weights to the location factors. In terms of the model this involves replacing the $\beta$ coefficients in the regression by $\beta_{M}$ where the $M$ index refers to the parent company-specific sensitivity towards the covariate. The econometric approach involves estimation of the so-called deep parameters that describe the moments of the distribution of parameters in the population (in our case the mean value of the $\beta_{M}$ parameters and their standard deviation). Variance in the unobserved firm-specific parameters induces correlation over alternatives in the stochastic portion of profits. Consequently, mixed logit does not exhibit the restrictive substitution and forecasting patterns of standard conditional logit. ${ }^{43}$ Additionally, it allows efficient estimation when there are repeated choices by the same decision makers, as it is the case in our application (Revelt and Train 1998).

However, there are computational problems associated with the usage of mixed logit. As the choice probabilities in the model do not have a closed form formulation, simulations need to be performed for the estimations. Draws and calculations from multidimensional distributions, though, are computationally very intensive. Therefore the implementations of the model are restricted in terms of the number of covariates that can be used and the STATA implementation prepared by Hole (2007) allows for a maximum of 20 variables. This implies that we cannot use any country fixed effects. Consequently, the question of endogeneity of environmental stringency becomes very pronounced. To deal with that potential issue we develop instruments for environmental stringency and combine our mixed logit estimations with the control function approach.

${ }^{43}$ Because of its flexibility, mixed logit can mimic any nested structure. 
Table 5 Effects of including parent productivity measure - coefficients from logit estimations

\begin{tabular}{|c|c|c|c|c|}
\hline & A & B & $\mathrm{C}$ & $\mathrm{D}$ \\
\hline gf \# dirty \# envir & $-.302 * *$ & $-.306^{* *}$ & $-.428 * * *$ & $-.427^{* *}$ \\
\hline gf \# clean \# envir & -.061 & -.064 & -.176 & -.175 \\
\hline MA \# dirty \# envir & .168 & .172 & .04 & .047 \\
\hline MA \# clean \# envir & .128 & .13 & .001 & .006 \\
\hline ctax & -.001 & -.001 & -.022 & -.023 \\
\hline gf \# ctax & -.025 & -.026 & & \\
\hline corrupt_freedom & .003 & .003 & .004 & .004 \\
\hline labor_freedom & $-.011^{*}$ & $-.01^{*}$ & -.006 & -.006 \\
\hline population & .232 & .225 & 1.07 & 1.023 \\
\hline gdpPerCap & -.314 & -.306 & -.202 & -.193 \\
\hline openness & .24 & .23 & .256 & .251 \\
\hline FDI_stock & .069 & .076 & .008 & .013 \\
\hline market capitalization & & & -.028 & -.028 \\
\hline MA \# market capitalization & & & .047 & .047 \\
\hline country FE & $\mathrm{x}$ & $\mathrm{x}$ & $\mathrm{x}$ & $\mathrm{x}$ \\
\hline country FE \# Gf FE & $\mathrm{x}$ & $\mathrm{x}$ & $\mathrm{x}$ & $\mathrm{x}$ \\
\hline country FE \# productivity ${ }_{M}$ & $\mathrm{x}$ & & $\mathrm{x}$ & \\
\hline Gf FE \# productivity ${ }_{M}$ & $\mathrm{x}$ & & $\mathrm{x}$ & \\
\hline country FE \# Gf FE \# productivity $_{M}$ & $\mathrm{x}$ & & $\mathrm{x}$ & \\
\hline Year FE \# Gf FE & $\mathrm{x}$ & $\mathrm{x}$ & $\mathrm{x}$ & $\mathrm{x}$ \\
\hline test dirty & $* * *$ & $* * *$ & $* * *$ & $* * *$ \\
\hline \multicolumn{5}{|l|}{ test clean } \\
\hline No. observ (in thsd.) & 819 & 819 & 569 & 569 \\
\hline Log pseudolik. & -26644 & -26732 & -22186 & -22258 \\
\hline
\end{tabular}

*** significance at $1 \%$ level, $* * 5 \%$-level, $* 10 \%$-level. Standard errors have been clustered at the investor level. All specifications run with observations with the parent productivity measure available. Results report coefficients rather than odds ratios. Source: Deutsche Bundesbank, Microdatabase Direct Investments (MiDi) 2005-2011, own calculations

We develop two alternative instruments: lagged environmental regulation (lag_env) and a measure of the external pressure on environmental regulation (ext_pressure). The latter instrument is constructed as a weighted average of the regulation level, as measured through the WEF index, in the countries (excluding Germany) that import the goods produced by a given country. The weights correspond to the shares of the partner countries in total exports. We use lagged regulation of the trade partners as we expect the effects of the pressure not to appear immediately.

To be a valid instruments, the variables must be correlated with the environmental stringency of the individual countries, while simultaneously being uncorrelated with the unexplained part of the location-entry mode decision. For the ext_pressure we expect the partner countries to exert pressure on the exporters in case the exporters' environmental regulations are lenient compared to the regulations of the importing partner. The pressure could come from various sources such as consumer groups, importing companies wanting to protect their "responsible" image, legislation imposing certain requirements on the imported goods, or exporters themselves who want to signal the quality of their products. 
With environmental regulation exhibiting relatively high stickiness, we expect lag_env to have strong predictive power for the green stringency. The latter condition requires "external pressure" and lagged environmental regulation to be uncorrelated with country-specific, time-varying factors that affect parent companies' choice of location and entry mode.

Our instrument ext_pressure resembles the one used by Levinson and Scott Taylor (2008) in their study of PHH in the trade context. They instrument the pollution costs faced by different sectors in the US between 1977 and 1986 by taking a weighted average of state characteristics, where the weights are the sector's value added in the various states at the beginning of the sample period.

We preserve the non-linear framework of our study, by instrumenting using a control function approach instead of $2 \mathrm{SLS}{ }^{44}$ The control function approach has some limitations compared to two-stage least squares. In particular, it requires the first-stage model to be correctly specified and the exactly right set of instruments to be found for the consistency of the estimators (Lewbel et al. 2012). However, we are encouraged to the usage of the method by its successful application in many areas, for example in the estimation of demand for differentiated products (see, e.g. Ferreira 2010).

Our implementation of the control function approach follows Petrin and Train (2009) with bootstrapped standard errors of the coefficients of the residual in the second stage.

To get an intuition for the importance of instrumenting the environmental stringency, we first use the IV strategy in our standard conditional logit framework before applying it to mixed logit estimations. The results are presented in Table 6. Column LAG1 reports the first stage for the lagged regulation used as instrument and EXT_P1 for the "external pressure" instrument. The instruments are interacted with investment type dummies like in the original Equation ( $g f \#$ dirty\#IV, gf\#clean\#IV, etc.), their $t$-values are 25 and 3, respectively.

The second stage (columns LAG2 and EXT_P2) uses, in addition to the baseline covariates, the predicted residuals (residual) from the first stage as an explanatory variable to account for any unmeasured confounders.

Table 6 confirms our previous findings that polluting Greenfields avoid environmentally stringent countries. At the same time, it shows no evidence for negative effect of regulation on propensity to perform an M\&A investment, in particular a clean one. The pronounced difference across the entry modes is also clearly visible in the test dirty statistic.

The residual from the first stage does not perform well as a predictor of firms' behavior. This suggests that endogeneity does not pose a serious problem for the estimates.

Next, we turn to the mixed logit analysis. Given the better performance of lagged environmental stringency in the first stage, we use it as an instrument for our IIA test.

Our goal is is to compare whether the environmental sensitivity coefficients exhibit substantial differences depending on the estimation technique used. If not, we would conclude that IIA assumption may not be too restrictive for our case and thus have higher confidence in our results.

\footnotetext{
44 Estimating a standard 2SLS corresponds to estimation of a linear probability which would not match the non-linear nature of the decision problem. Additionally, with 2SLS not only the environmental stringency needs to be instrumented but also all nonlinear functions of it, which in our case are four interaction terms. Combining a linear first stage regression with a simplified logit model on the second stage is not appropriate (Angrist and Pischke 2008, p.192).
} 
Table 6 Instrumenting the environmental regulation using lagged environmental regulation (LAG) and external pressure (EXT_P)

\begin{tabular}{|c|c|c|c|c|}
\hline & LAG1 & LAG2 & EXT_P1 & EXT_P2 \\
\hline residual & & -.064 & & $1.01 *$ \\
\hline gf\# dirty \# IV & $.762 * * *$ & & $.14 * * *$ & \\
\hline gr \# clean \# IV & $.761 * * *$ & & $.14 * * *$ & \\
\hline MA \# dirty \# IV & $.759 * * *$ & & $.158^{* * * *}$ & \\
\hline$M A$ \# clean \# IV & $.755^{* * * *}$ & & $.156^{* * *}$ & \\
\hline gf\# dirty \# envir & & $-.508^{* * *}$ & & $-1.519^{* *}$ \\
\hline gr \# clean \# envir & & $.161 * *$ & & -.844 \\
\hline MA \# dirty \# envir & & .015 & & -.975 \\
\hline MA \# clean \# envir & & $.372^{* * *}$ & & .616 \\
\hline $\operatorname{ctax}$ & $.003^{*}$ & $-.019 * * *$ & $.007 * * *$ & $-.013^{* * *}$ \\
\hline gr\# tax & .000 & $.016^{* * *}$ & $.001 * * *$ & $.018^{* * * *}$ \\
\hline corrupt_freedom & $.008 * * *$ & -.002 & $.032^{* * *}$ & .03 \\
\hline labor_freedom & .001 & -.001 & $.003 * *$ & .022 \\
\hline population & .012 & $.407 * * *$ & $.098^{* * *}$ & $.495^{* * * *}$ \\
\hline gdpPerCap & .014 & $.545 * * *$ & .06 & $.606^{* * * *}$ \\
\hline openness & .007 & -.01 & .08 & .053 \\
\hline FDI_stock & -.011 & $.42 * * *$ & $-.054^{*}$ & $.37 * * *$ \\
\hline test dirty & & $* * *$ & & $* * *$ \\
\hline test clean & & $* * *$ & & $* * *$ \\
\hline $\mathrm{R} 2$ & 0.28 & & 0.41 & \\
\hline No. observ (in thous.) & 1984.4 & 1984.4 & 1854.5 & 1854.5 \\
\hline Log pseudolik. & & -40117 & & -38410 \\
\hline
\end{tabular}

In the " 1 " columns, the environmental stringency is the dependent variable with lagged environmental regulation (specification LAG) and external pressure (EXT_P) used as instruments. The columns "2" report the second stage with residuals from the first stage plugged in. Clustering in the first stage is at the countryyear level as we rely on country-level variability, in the second at investor level. Standard errors of the residual coefficients are bootstrapped. Year-Greenfield fixed effects are present in all specifications. Results report coefficients rather than odds ratios. *** significance at $1 \%$ level, ** 5\% level, * $10 \%$ level.

Source: Deutsche Bundesbank, Microdatabase Direct Investments (MiDi) 2005-2011, own calculations

Table 7 presents the estimated coefficients for conditional logit and the means of individual $\beta_{M}$ parameters for mixed logit. ${ }^{45}$ For most of the covariates both the estimated magnitudes and significance levels are very close (e.g. residual, population, gdpPerCap). Only for two variables (openness and MA\#dirty\#envir) differences emerge. ${ }^{46}$ It is also worth noticing that the PHH-relevant estimates are in strong agreement with those from main specification (column I, Table 3 ). This is an indication that the IIA does not exert a crucial

\footnotetext{
45 To assure reasonably low simulation errors in the estimated parameters 240 Halton draws were used. Train (2002) discusses the efficiency of Halton draws compared to random draws and concludes that with random draws, the simulation variance decreases at a rate of approximately $1 / R$, where $R$ is the number of draws whereas with the Halton draws, the rate of decrease is faster: doubling the number of draws decreases the simulation variance by a factor of about three.

${ }^{46}$ The much better fit of the mixed logit estimation stems from it fitting individual coefficients $\beta_{i}$ instead of the population-wide coefficients, $\beta$, like conditional logit.
} 
Table 7 Testing for the importance of the IIA assumption

\begin{tabular}{lll}
\hline & Conditional logit & Mixed logit \\
\hline residual & -.057 & -.061 \\
gf \# dirty \# envir & $-.517^{* * *}$ & $-.751^{* * *}$ \\
gr\# clean \#e nvir & $.151^{* *}$ & $.084^{*}$ \\
MA \# dirty \# envir & .01 & $-.095^{*}$ \\
MA \# clean \# envir & $.363^{* * *}$ & $.274^{* * *}$ \\
ctax & $-.018^{* * *}$ & $-.022^{* * *}$ \\
gr\# ctax & $.016^{* * *}$ & $.009^{* * *}$ \\
corrupt_freedom & -.002 & -.002 \\
population & $.406^{* * *}$ & $.374 * * *$ \\
gdpPerCap & $.541^{* * *}$ & $.54 * * *$ \\
openness & -.013 & $-.109^{* * *}$ \\
distance & $-.312^{* * *}$ & $-.445^{* * *}$ \\
FDI_stock & $.416^{* * *}$ & $.465^{* * *}$ \\
No observ (in thous.) & 1984.4 & 1984.4 \\
Log pseudolik. & -40118 & -36654 \\
\hline
\end{tabular}

The table reports the coefficients from the second stage of a control function approach for conditional logit and mixed logit. Lagged environmental regulation used in the first stage ( $t$-value of 32). Clustering is at investor level. Standard errors for the residual coefficients of the residual coefficients are bootstrapped. Year-Greenfield fixed effects are included but not reported. *** significance at $1 \%$ level, ** 5\% level, * $10 \%$ level. Source: Deutsche Bundesbank, Microdatabase Direct Investments (MiDi) 1999-2011, own calculations

influence on the estimation results and is not the driving force behind our findings on the effect of environmental regulation.

\section{Economic Importance of the Results and Policy Implications}

Although we find strong indications for environmental regulation exerting a statistically significant influence on some types of FDI investments, the economic significance of that relationship remains to be shown. To that end, we simulate the effects of increasing environmental regulation for various countries. Marginal effects are determined by all the independent variables at the same time; therefore, a comparison of several countries allows us to fully explore the importance of environmental policy. We concentrate on the US, France, China and the UK-vital hosts for German foreign investments as shown in Fig. 1 that, at the same time, happen to be quite diverse in terms of their environmental policies, openness, taxation, etc.

Table 8 reports results based on our main specification - conditional logit with countryentry mode fixed effects, shown in column (I) from Table 3 . In our investigation of relevance of the $\mathrm{PHH}$ we decided to concentrate on dirty projects. For every location, the 
Table 8 The impact of an increase in environmental stringency on probability of attracting a new investment

\begin{tabular}{lllll}
\hline & Dirty M\&A & Dirty Gf & Dirty M\&A & Dirty Gf \\
\hline & France & & Great Britain & \\
Standard dev. change & -.009 & -.005 & -.011 & -.005 \\
Elasticity & -.511 & -1.851 & -.524 & -1.916 \\
Probability & .051 & .01 & .064 & .009 \\
& USA & & China & \\
Standard dev. change & -.011 & -.018 & -.005 & -.022 \\
Elasticity & -.431 & -1.722 & -.215 & -.848 \\
Probability & .074 & .037 & .032 & .044 \\
\hline
\end{tabular}

Note: Simulations are based on regression results from column (I) of Table 3

simulated effects of a one standard deviation change in environmental stringency ${ }^{47}$ on the propensity of attracting the two types of projects are reported in the upper row. The lowest row (probability) shows the initial investment propensity as a benchmark to enable the reader assessing the economic importance of the changes. The middle row of the table presents the respective elasticities.

The implied impact on dirty Greenfield projects is sizeable. We predict that raising environmental regulation by 0.91 units would about halve the probability of attracting a dirty investment in the form of a Greenfield. This would translate into a significant number of projects lost in countries such as China and the USA which attract numerous dirty investments through that mode. It is conceivable that some of those Greenfields would be performed as M\&As instead. Unfortunately, our identification strategy does not allow us to disentangle the substitution patterns to compute the respective cross-elasticities.

However, even without any substitution between the modes of entry our results indicate that the environmental policies may affect not only the level of FDI but also its composition.

As in the case of the the USA and China, for France and Great Britain, our simulated elasticities are roughly four times as large in the case of dirty Greenfield projects compared to dirty M\&As. However, given that these countries have currently low probability of receiving a dirty Greenfield investments, that elasticity translates in low absolute change in investment probability.

\section{Discussion}

Policymakers in some of the industrialized countries have been balking at sharpening their environmental requirements out of fear of impairing the international competitiveness of their economies and job losses. They tend to support their arguments with predictions of

\footnotetext{
47 A one standard deviation increases the environmental stringency index by 0.919 . This constitutes a substantial change and roughly corresponds to Belgium imposing stricter environmental legistation in 2010 to match the Swiss level.
} 
the pollution haven hypothesis. However, even though a host of studies on the PHH has been conducted, empirically the PHH is still disputed as the evidence has been mixed.

This paper is an empirical analysis of whether, and if yes, to what extent, the German investment location decisions are sensitive towards the spatial variation of the environmental regulation. Our main contribution has been to distinguish between different modes of entry. Using the information on the German outbound FDI in 2005-2011, we demonstrate that the M\&A projects respond to a lesser extent to pollution requirements than do Greenfield projects and that the governments can indirectly influence the composition of FDIs by setting environmental standards.

The differential effect of environmental regulation on FDIs is not only statistical significant, but also sizeable. Our simulations based on nonlinear regressions suggest that the elasticity for polluting Greenfield projects is roughly four times higher than for polluting M\&As in important host countries of German FDI. We conjecture therefore that the diverging results delivered by previous studies of the PHH could be partly explained by their different composition of the investments in terms of the mode of entry that was not controlled for. Our results suggest that a high (yet unreported) fraction of M\&A projects could be behind the sometimes insignificant results.

These results suggest that with sharpened environmental regulations, the prevalence of M\&A investments raises. This has important implications for host countries as demonstrated by Becker and Fuest (2011), who model the effects of both of the entry modes on the tax base and on tax competition. Harms and Méon (2018) show empirically that Greenfields are associated with higher GDP growth rates compared to mergers. On the other hand, Davies and Desbordes (2015) indicate that outbound Greenfield investments may have much stronger negative effects on an origin country's labor market than do M\&As.

Increased restrictiveness of regulation seems to have neutral and, in some of our specifications, a weakly positive effect on the decision to locate clean M\&As in the respective jurisdiction. This latter finding could be due to the "green image" that German firms are trying to promote or due to the firms switching the entry mode for their investments.

Our main results are robust to different specifications, including an alternative measure of environmental stringency, an exclusion of the service sector, and the use of a mixed logit model instead of conditional logit. The robustness holds also for the use of a control function specification that addresses possible endogeneity.

Despite these robust results further research in this area is worthwhile, especially studying other investor countries. The PHH literature suggests that the response to host countries' environmental stringency depends on the environmental stringency in the parent firm's country (Cai et al. 2016). It is thus conceivable that the differences between M\&A and Greenfield sensitivity to environmental regulations are even higher for investments originating from less regulated countries. Such a result would imply even higher trade-offs associated with increasing environmental stringency. In addition, a more direct identification of the role of vintage differentiation would be helpful for studying economic implications of the VDRs. Even though vintage differentiation is widely present in the environmental regulation, the provisions tend to be also overlooked in the economic literature and their optimal design is not yet well understood. For cleaner identifications of the effects, a measure of VDRs across countries or sectors would be a highly welcome input. 


\section{Appendix: Classification of the Industries According to their Pollution Intensity}

\begin{tabular}{|c|c|c|c|c|c|}
\hline Code & Industry & Poll. clas. & Code & Industry & Poll. clas. \\
\hline 1500 & Food production & $\mathrm{H}$ & 6410 & Post and telecommunications & $\mathrm{H}$ \\
\hline 1600 & Tabacco products & $\mathrm{H}$ & 6570 & Financial leasing & $\mathrm{L}$ \\
\hline 1700 & Manufacture of textiles & $\mathrm{H}$ & 6580 & Other financial intermediaries & $\mathrm{L}$ \\
\hline 1800 & Manufacture of textile products & $\mathrm{L}$ & 6590 & Investment funds & $\mathrm{L}$ \\
\hline 1900 & $\begin{array}{l}\text { Manufacture of leather, leather } \\
\text { products }\end{array}$ & $\mathrm{L}$ & 6600 & Insurance and pension funds & $\mathrm{L}$ \\
\hline 2000 & $\begin{array}{l}\text { Manufacture of wood and wood } \\
\text { products }\end{array}$ & $\mathrm{H}$ & 6700 & $\begin{array}{l}\text { Activities auxiliary to financial } \\
\text { intermediation }\end{array}$ & $\mathrm{L}$ \\
\hline 2100 & $\begin{array}{l}\text { Manufacture of pulp and paper } \\
\text { products }\end{array}$ & $\mathrm{H}$ & 7050 & Housing enterprises & $\mathrm{H}$ \\
\hline 2200 & $\begin{array}{l}\text { Publishing, printing and repro- } \\
\text { duction of recorded media }\end{array}$ & $\mathrm{H}$ & 7060 & Other real estate activities & $\mathrm{H}$ \\
\hline 2300 & $\begin{array}{l}\text { Manufacture of coke, refined } \\
\text { petroleum products, etc. }\end{array}$ & $\mathrm{H}$ & 7100 & $\begin{array}{l}\text { Renting of machinery and equip- } \\
\text { ment without operator }\end{array}$ & $\mathrm{L}$ \\
\hline 2400 & $\begin{array}{l}\text { Manufacture of chemicals and } \\
\text { chemical products }\end{array}$ & $\mathrm{H}$ & 7200 & Computer and related activities & $\mathrm{L}$ \\
\hline 2440 & $\begin{array}{l}\text { Manufacture of pharmaceutical } \\
\text { products }\end{array}$ & $\mathrm{H}$ & 7300 & Research and development & $\mathrm{L}$ \\
\hline 2500 & $\begin{array}{l}\text { Manufacture of rubber and plas- } \\
\text { tic products }\end{array}$ & $\mathrm{H}$ & 7411 & Legal activities & $\mathrm{L}$ \\
\hline 2600 & $\begin{array}{l}\text { Manufacture of other non-metal- } \\
\text { lic mineral products }\end{array}$ & $\mathrm{H}$ & 7412 & $\begin{array}{l}\text { Accounting, book-keeping and } \\
\text { auditing activities }\end{array}$ & $\mathrm{L}$ \\
\hline 2700 & Manufacture of basic metals & $\mathrm{H}$ & 7413 & $\begin{array}{l}\text { Market research and public opin- } \\
\text { ion polling }\end{array}$ & $\mathrm{L}$ \\
\hline 2800 & Manufacture of metal products & $\mathrm{H}$ & 7414 & $\begin{array}{l}\text { Business and management con- } \\
\text { sultancy activities }\end{array}$ & $\mathrm{L}$ \\
\hline 2900 & $\begin{array}{l}\text { Manufacture of machinery and } \\
\text { equipment n.e.c. }\end{array}$ & $\mathrm{L}$ & 7420 & $\begin{array}{l}\text { Architectural and engineering } \\
\text { activities and related technical } \\
\text { consultancy }\end{array}$ & $\mathrm{L}$ \\
\hline 3000 & $\begin{array}{l}\text { Manufacture of office machinery } \\
\text { and computers }\end{array}$ & $\mathrm{L}$ & 7430 & Technical testing and analysis & $\mathrm{H}$ \\
\hline 3100 & $\begin{array}{l}\text { Manufacture of electrical } \\
\text { machinery and apparatus n.e.c. }\end{array}$ & $\mathrm{L}$ & 7440 & Advertising & $\mathrm{L}$ \\
\hline 3200 & $\begin{array}{l}\text { Manufacture of radio, television } \\
\text { and communication equipment } \\
\text { and apparatus }\end{array}$ & $\mathrm{L}$ & 7450 & $\begin{array}{l}\text { Labor recruitment and provision } \\
\text { of personnel }\end{array}$ & $\mathrm{L}$ \\
\hline 3300 & $\begin{array}{l}\text { Manufacture of medical, preci- } \\
\text { sion and optical instruments }\end{array}$ & $\mathrm{L}$ & 7460 & $\begin{array}{l}\text { Investigation and security activi- } \\
\text { ties }\end{array}$ & $\mathrm{L}$ \\
\hline 3400 & $\begin{array}{l}\text { Manufacture of motor vehicles, } \\
\text { trailers and semi-trailers }\end{array}$ & $\mathrm{H}$ & 7470 & Industrial cleaning & $\mathrm{L}$ \\
\hline 3510 & $\begin{array}{l}\text { Building and repairing of ships } \\
\text { and boats }\end{array}$ & $\mathrm{L}$ & 7480 & $\begin{array}{l}\text { Miscellaneous business activities } \\
\text { n.e.c }\end{array}$ & $\mathrm{L}$ \\
\hline 3520 & Manufacture of railed vehicles & $\mathrm{L}$ & 7490 & $\begin{array}{l}\text { Management activities of holding } \\
\text { companies }\end{array}$ & $\mathrm{L}$ \\
\hline 3530 & $\begin{array}{l}\text { Manufacture of aircraft and } \\
\text { spacecraft }\end{array}$ & $\mathrm{L}$ & 8000 & Education & $\mathrm{L}$ \\
\hline
\end{tabular}




\begin{tabular}{|c|c|c|c|c|c|}
\hline Code & Industry & Poll. clas. & Code & Industry & Poll. clas. \\
\hline 3540 & $\begin{array}{c}\text { Manufacture of motorcycles, } \\
\text { bicycles, invalid carriages }\end{array}$ & $\mathrm{L}$ & 8500 & Health and social work & $\mathrm{L}$ \\
\hline 3550 & $\begin{array}{l}\text { Manufacture of other transport } \\
\text { equipment n.e.c. }\end{array}$ & $\mathrm{L}$ & 9000 & $\begin{array}{l}\text { Sewage and refuse disposal, } \\
\text { sanitation }\end{array}$ & $\mathrm{H}$ \\
\hline 3600 & $\begin{array}{l}\text { Manufacure of furniture, manu- } \\
\text { facturing n.e.c. }\end{array}$ & $\mathrm{H}$ & 9100 & $\begin{array}{l}\text { Activities of other membership } \\
\text { organizations. }\end{array}$ & $\mathrm{L}$ \\
\hline 3700 & Recycling & $\mathrm{H}$ & 9210 & $\begin{array}{l}\text { Motion picture and video activi- } \\
\text { ties }\end{array}$ & $\mathrm{L}$ \\
\hline 4000 & $\begin{array}{l}\text { Electricity, gas, steam and hot } \\
\text { water supply }\end{array}$ & $\mathrm{H}$ & 9220 & Radio and television activities & $\mathrm{L}$ \\
\hline 4100 & $\begin{array}{l}\text { Collection, purification and } \\
\text { distribution of water }\end{array}$ & $\mathrm{H}$ & 9230 & Other entertainment activities & $\mathrm{L}$ \\
\hline 4500 & Construction sector & $\mathrm{H}$ & 9240 & News agency activities & $\mathrm{L}$ \\
\hline 5000 & $\begin{array}{l}\text { Sale, repair of motor vehicles; } \\
\text { retail sale of automotive fuel }\end{array}$ & $\mathrm{L}$ & 9250 & $\begin{array}{l}\text { Library, archives, museums, } \\
\text { other cultural activities }\end{array}$ & $\mathrm{L}$ \\
\hline 5100 & $\begin{array}{l}\text { Wholesale trade and commission } \\
\text { trade }\end{array}$ & $\mathrm{L}$ & 9260 & Sporting activities & $\mathrm{L}$ \\
\hline 5200 & $\begin{array}{l}\text { Retail trade, repair of personal } \\
\text { goods }\end{array}$ & $\mathrm{L}$ & 9270 & Other recreational activities & $\mathrm{L}$ \\
\hline 5500 & Hotels and restaurants & $\mathrm{L}$ & 9300 & Other service activities n.e.c & $\mathrm{L}$ \\
\hline
\end{tabular}

Funding Open Access funding enabled and organized by Projekt DEAL.

Open Access This article is licensed under a Creative Commons Attribution 4.0 International License, which permits use, sharing, adaptation, distribution and reproduction in any medium or format, as long as you give appropriate credit to the original author(s) and the source, provide a link to the Creative Commons licence, and indicate if changes were made. The images or other third party material in this article are included in the article's Creative Commons licence, unless indicated otherwise in a credit line to the material. If material is not included in the article's Creative Commons licence and your intended use is not permitted by statutory regulation or exceeds the permitted use, you will need to obtain permission directly from the copyright holder. To view a copy of this licence, visit http://creativecommons.org/licenses/by/4.0/.

\section{References}

Aichele R, Felbermayr G (2012) Kyoto and the carbon footprint of nations. J Environ Econ Manag 63:336-354

Angrist JD, Pischke JS (2008) Mostly harmless econometrics, an empiricists companion. Princeton University Press, Princeton

Barrios S, Huizinga H, Laeven L, Nicodeme G (2012) International taxation and multinational firm location decisions. J Public Econ 96(11-12):946-958

Bartik TJ (1988) The effects of environmental regulation on business location in the United States. Growth Chang 19:22-44

Becker J, Fuest C (2011) Tax competition - Greenfield investment versus mergers and acquisitions. Reg Sci Urban Econ 41:476-486

Blank S, Lipponer A, Schild C-J, Scholz D (2020) Microdatabase direct investment (MiDi) - a full survey of German inward and outward investment. German Econ Rev 21(3):273-311

Botta E, Kozluk T (2014) Measuring environmental policy stringency in OECD countries: a composite index approach. Economics department working papers No. 1177. OECD

Brunnermeier S, Levinson A (2004) Examining the evidence on environmental regulations and industry location. J Environ Dev 13:6-41

Cai X, Lu Y, Wu M, Yu L (2016) Does environmental regulation drive away inbound foreign direct investment? Evidence from a quasi-natural experiment in China. J Dev Econ 123:73-85 
Carlton D (1983) Location and employment choices of new firms: an econometric model with diescete and continuous endogenous variables. Rev Econ Stat 65:440-449

Chung S (2014) Environmental regulation and foreign direct investment: evidence from South Korea. J Dev Econ 108:222-236

Cole MA, Elliott RJR (2005) FDI and the capital intensity of dirty sectors: a missing piece of the pollution haven puzzle. Rev Dev Econ 9(4):530-548

Cole MA, Elliott RJR, Zhang L (2017) Foreign direct investment and the environment. Annu Rev Environ Resour 42:465-487

Davies RB, Desbordes R (2015) Greenfield FDI and skill upgrading: a polarized issue. Can J Econ 48:207-244

Davies RB, Desbordes R, Ray A (2018) Greenfield versus merger and acquisition FDI: same wine, different bottles? Can J Econ 51:1151-1190

Dean JM, Lovely ME, Wang H (2009) Are foreign investors attracted to weak environmental regulations? Evaluating the evidence from China. J Dev Econ 90:1-13

Dong B, Gong J, Zhao X (2012) FDI and environmental regulation: pollution haven or a race to the top? J Regul Econ 41:216-237

Ederington J, Levinson A, Minier J (2005) Footloose and pollution-free. Rev Econ Stat 87:92-99

Elliott RJR, Zhou Y (2013) Environmental regulation induced foreign direct investment. Environ Resource Econ 55:141-158

Eskeland GS, Harrison AE (2003) Moving to greener pastures? Multinationals and the pollution haven hypothesis. J Dev Econ 70(1):1-23

Ferreira F (2010) You can take it with you: proposition 13 tax benefits, residential mobility, and willingness to pay for housing amenities. J Public Econ 94:661-673

Fredriksson PG, List JA, Millimet DL (2003) Bureaucratic corruption, environmental policy and inbound US FDI: theory and evidence. J Public Econ 87(7):1407-1430

Fujita M (2008) A critical assessment of FDI data and policy implications. Transnatl Corp 17:107-126

Graeker M, Rosenthal KE (2008) Environmental policy with upstream pollution abatement technology firms. J Environ Econ Manag 56(3):246-259

Greenland S, Schwartzbaum JA, Finkle WD (2000) Problems due to small samples and sparse data in conditional logistic regression analysis. Am J Epidemiol 151:531-539

Rema H (2010) US environmental regulation and FDI: evidence from a panel of US-based multinational firms. Am Econ J Appl Econ 2:158-189

Harms P, Méon P-G (2018) Good and useless FDI: the growth effects of greenfield investment and mergers and acquisitions. Rev Int Econ 26:37-59

Hebous S, Ruf M, Weichenrieder AJ (2011) the effects of taxation on the location decision of multinational firms: M\&A vs greenfield investments. Natl Tax J 64:817-838

Hole AR (2007) Fitting mixed logit models by using maximum simulated likelihood. Stata J 7:388-401

Huizinga H, Voget J, Wagner W (2012) Who bears the burden of international taxation? Evidence from cross-border M\&As. J Int Econ 88:186-197

Javorcik B, Wei S-J (2005) Pollution havens and foreign direct investment: dirty secret or popular myth? BE J Econ Anal Policy 2:8-40

Kellenberg DK (2009) An empirical investigation of the pollution haven effect with strategic environment and trade policy. J Int Econ 78:242-255

Keller W, Levinson (2002) Pollution abatement costs and foreign direct investment inflows to US states. Rev Econ Stat 84:691-703

Kheder SB, Zugravu N (2012) Environmental regulation and french firms location abroad: an economic geography model in an international comparative study. Ecol Econ 77:48-61

Kozluk T, Garsous G (2016) How stringent are environmental policies? OECD

Kozluk T (2014) The indicators of the economic burdens of environmental policy design - results from the OECD questionnaire

Levinson A, Taylor SM (2008) Unmasking the pollution haven effect. Int Econ Rev 49:223-254

Levinson A (1996) Environmental regulations and manufacturers location choices: evidence from the census of manufactures. J Public Econ 62:5-29

Levinson A (2010) Pollution and international trade in services. Int Environ Agreem Polit Law Econ 10:93-105

Lewbel A, Dong Y, Yang TT (2012) Comparing features of convenient estimators for binary choice models with endogenous regressors. Can J Econ 45:809-829

List JA, Co CY (2000) The effects of environmental regulations on foreign direct investment. J Environ Econ Manag 40:1-20 
List JA (2001) US county-level determinants of inbound FDI: evidence from a two-step modified count data model. Int J Ind Organ 19:953-973

Manderson E, Kneller R (2011) Environmental regulations, outward FDI and heterogeneous firms: are countries used as pollution havens? Environ Resource Econ 51:317-352

Melitz MJ (2003) The impact of trade on intra-industry reallocations and aggregate industry productivity marc. Econometrica 71:1695-1725

Naughton H T (2014) To shut down or to shift: multinationals and environmental regulation. Ecol Econ 102:113-117

Ng FK (2011) Data on trade and import barriers. Trade Research, World Bank

Nocke V, Yeaple S (2008) An assignment theory of foreign direct investment. Rev Econ Stud 75:529-557

Perez-Saiz H (2015) Building new plants or entering by acquisition? Firm heterogeneity and entry barriers in the US cement industry. RAND J Econ 46(3):625-649

Petitt BS, Ferris KR (2013) Valuation for mergers and acquisitions, 2nd edn. FT Press, New Jersey

Petrin A, Train K (2009) A control function approach to endogeneity in consumer choice models. J Mark Res 47:3-13

Poelhekke S, van der Ploeg F (2014) Green havens and pollution havens. World Econ 38:1159-1178

Raspiller S, Riedinger N (2008) Do environmental regulations influence the location behavior of french firms? Land Econ 84(3):382-395

Revelt D, Train K (1998) Mixed logit with repeated choices: households choices of appliance efficiency level. Rev Econ Stat 80:647-657

Rezza AA (2013) FDI and pollution havens: evidence from the norwegian manufacturing sector. Ecol Econ 90:140-149

Rezza AA (2015) A meta-analysis of FDI and environmental regulations. Environ Dev Econ 20:1-24

Statistisches Bundesamt (2011) Umwelt. Investitionen für den Umweltschutz im Produzierenden Gewerbe, (2009) Fachserie 19. Reihe 3(1)

Stavins RN (2006) Vintage-differentiated environmental regulation. Stanford Environ Law J 25:29-63

Stepanok I (2015) Cross-border Mergers and Greenfield Foreign Direct Investment. Rev Int Econ 23:111-136

Train K (2001) Halton sequences for mixed logit. Econometrics 001:2001

US Census Bureaus (2008) Pollution abatement costs and expenditures 2005. Current industrial reports 200(05)

van Soest DP, List JA, Jeppesen T (2006) Shadow prices, environmental stringency, and international competitiveness. Eur Econ Rev 50:1151-1167

Wagner UJ, Timmins CD (2009) Agglomeration effects in foreign direct investment and the pollution haven hypothesis. Environ Resource Econ 43:231-256

Wei S-J (2000) How taxing is corruption on international investors? Rev Econ Stat 82(1):1-11

Xing Y, Kolstad CD (2002) Do lax environmental regulations attract foreign investment? Environ Resource Econ 21:1-22

Publisher's Note Springer Nature remains neutral with regard to jurisdictional claims in published maps and institutional affiliations. 